\title{
Los escritores vistos por los artistas
}

\author{
$M^{a}$ TeResa JiMENEZ
}

El tema de la representación artística de grupos literarios o de literatos agrupados, y la relación entre plástica y poesía está poco estudiada principalmente a partir de obras concretas. Contrariamente a lo que sucede con los equipos de actores dramáticos, músicos y hasta los mismos artistas plásticos que han sido objeto de reiteradas investigaciones y publicaciones.

Basta recorrer el Gabinete de Estampas de la Biblioteca Nacional de París, la casa -museo de Balzac y Victor Hugo, la Biblioteca Nacional de Madrid, los fondos del Museo Romántico, los del Centro de Cultura de Portugal en Paris, etc., por los que anduvimos, junto a la prensa de todas las épocas, para comprobar que existen múltiples representaciones de este tema ignoradas hasta el presente o no apreciadas en su valor.

El acopio obtenido en esta prolongada búsqueda es superior al que, en principio, podiamos imaginar.

En este trabajo damos una selección de estas representaciones con unas consideraciones sumarias del tema, ya que un estudio profundo nos llevaria a abordar otros muchos aspectos que dilatarian la extensión concedida al presente. Por ello los emplazamos para ulteriores investigaciones.

Geográficamente reducimos nuestro campo a Francia y España, y sólo a las producciones de los siglos XVIII, XIX y XX.

Estas representaciones nos han llevado a emparejar recuerdos y noticias de tertulias y grupos literarios que cobraron vida, alcanzaron su auge y declinaron hasta desaparecer durante el periodo determinado que hemos elegido para nuestro estudio. Nos hacen seguir al escritor en su vida 
privada (Voltaire levantándose, en Ferney), en el momento crítico de su inspiración (Diderot, por Van Loo), esciribiendo en el café o difundiendo en solitario sus obras (Gabriel y Galán).

Otras veces lo contemplaremos en actividades académicas (Recepción de Victor Hugo, por ejemplo) o compartiendo sus inquietudes culturales en agrupaciones privadas (Lectura en casa de Mme. de Geoffrin) o instigando con afanes políticos (Escritores presidentes durante la I República).

Todo ello nos lleva a concluir que la vida literaria no margina sino que induce a participar de forma pletórica en las diversas facetas de la vida, ya sean amistosas, sociales, políticas, culturales, etc. Y el arte, una vez más, aporta creaciones en las que aúna la intencionalidad estética con una finalidad testimonial histórica o de documento.

Este es el proceso que pretendemos seguir en este camino.

Como precedente o pórtico al siglo xVIII, siglo del pensamiento y la razón, tenemos dos pinturas que, aunque realizadas en el siglo XVII y sobre personajes de esa época, su carácter preludia el que predominará en el siglo siguiente.

Nos referimos al lienzo de Dumesnil en que presenta al filósofo francés "Descartes en la Corte de la Reina Cristina de Suecia" (expuesto en el palacio de Versalles) y al de Henri Testelin inmortalizando el «Establecimiento de la Academia de Ciencias por Luis XIV en 1666 y la fundación del Observatorio en 1667" (custodiado también en Versalles).

Ambos tienen semejantes caracteres, grandes proporciones y ambiente cientifico, ampuloso y solemne.

Ambas escenas se desarrollan sobre un fondo de arquitectura clásica con un vano central que se abre a amplias perspectivas magnificarido el espacio. Los elegantes trajes de época completan el carácter de distinción.

La ambientación es científica también en los dos -planos, mapas, esferas, cuadrantes, libros-. Y, si en el primero Descartes es la figura central, exponiendo sus tesis ante la prestigiosa Corte de Suecia, en el cuadro de Testelín, Colbert presenta al Rey Sol al físico Edme Mariotte, uno de los fundadores de la Física experimental en Francia.

Las creaciones del siglo XVIII se centran, en Francia, en la actividad de los Salones y la publicación de la Enciclopedia y, en España, en la defensa de cuestiones polémicas de carácter religioso o político.

A pesar de no ser el retrato el primero en la jerarquía de los géneros, 
sin embargo su representatividad en los Salones fue tal que, en 1669, Bachaumont, se indigna por su número, que ese año llega al tercio de los cuadros expuestos. "Gracias al mal gusto del siglo -exclama- el Salón insensiblemente será sólo una galería de retratos».

Los escritores, en el arte del siglo XVIII, son muy estimados y sus retratos llegan a tener una gran importancia. Voltaire y Rousseau serán los más representados, tanto bajo formas favorables como ridículas. El siglo XVIII es una época en que, para una sociedad de burgueses y de señores cultivados, espirituales, refinados, se despliega un espíritu optimista, con una sensibilidad a flor de piel. Los pintores y grabadores que la representan desarrollan un arte esencialmente amable. En el siglo XVIII los retratos parecen vivos, tomados en una fogosa discusión. El brío y el movimiento rompen la fachada ceremoniosa, y el arte rápido de los pastelistas permite una prodigiosa vivacidad de expresión. El retrato admite todas las tendencias, exalta o poetiza la sociedad' 1 .

El siglo XVII expira con Luis XIV; durante la regencia la obra literaria es combativa, el espíritu crítico, antes dominado por la autoridad, reaparece. La influencia de los escritores crece a través de los Salones y, hacia mitad de siglo, existe una general efervescencia. Las ciencias progresan grandemente -se publican los primeros tomos de la Historia Natural de Buffon y de la Enciclopedia-. Los escritores tocan temas científicos y surge una lucha intelectual. Juan Jacobo Rousseau vitupera la sociedad hipócrita e inmoral de su tiempo. En este medio, el escritor agranda su papel social hasta ser esencial en la segunda mitad de este siglo de las luces ${ }^{2}$. Pasa de ser considerado inútil y dañino ${ }^{3}$ a que se piense que ser autor es un estado como ser militar, magistrado o financiero, en el que quieren ser admitidas otras clases sociales ${ }^{4}$. Su escalada es tan rápida que Malesherbes $^{5}$ los considera como los que poseen el talento de instruir al pueblo, ávido de saber, y el don de "moverlo" y aún añade: "estos hombres de letras... son en medio del pueblo disperso lo que eran los oradores de Roma y Atenas en medio del pueblo reunido". Fue entonces cuando se formó entre nosotros lo que hemos llamado el dominio de la opinión públi$\mathrm{Ca}^{6}$. Los escritores llegan a ser el símbolo de la nación y pasan a estimar-

' Sfrullaz, Grandes figures de France à travers I'histoire décrites et peintes par leurs contemporains. Paris. Diderot, 1969.

? PelLISSON, L'écrivaint et la societé du XVIII' siècle. Paris, Armand Collin, 1911, pág. 37.

${ }^{3}$ Discurso pronunciado en la Academia francesa el 28 de diciembre de 1724 en la recepción del presidente Portait.

- Raymond de Saint Saubfr, Agenda des Auteurs, 1754.

- Discours de réception à l'Academie Française, 1775.

${ }^{6}$ Rulmiere, Discours de réception à l'Académie Francaise, 4 de junio de 1787. 
los los extranjeros más que a los grandes señores ${ }^{7}$. Los hombres de letras a menudo eran el objeto de numerosos homenajes o de aclamaciones en el momento de su aparición en público. Estos homenajes podian tomar, a veces, formas originales, por ejemplo, los armadores llegaban hasta bautizar sus barcos con los nombres de Voltaire, d'Alembert, Jean-Jacques, Marmontel. Su ascensión había sido lenta y peligrosa, pero victoriosa.

Los salones, nacidos en 1663, por iniciativa de la Academia real de pintura y escultura y que celebraban exposiciones todos los años, sufren interrupción a causa de la guerra de 1704 a 1725. Además existen otras exposiciones, en la misma época, en la Academia de San Lucas, en el Salón de la Correspondencia y en el Salón de la Juventud. Pero éstas tienen menor importancia que las de los Salones de la Academia.

Los Salones eran, para los artistas, el gran acontecimiento en que habian de participar; en cambio, para las mujeres, era una reunión mundana que tenia toda la importancia de una institución.

No hay que ver -escribe Gall ${ }^{8}$ - al salón del siglo XVIII a imagen y semejanza de los de nuestros días. No es un lugar tranquilo, intimo, donde hablan cuatro o cinco personas con una taza de té en la mano. Por el contrario, es una habitación muy grande, con muchas ventanas, balcones y una amplia chimenea. En estos salones hay una multitud y uno va a ellos para hacerse ver, para establecer relaciones y para brillar. Es algo como lo que en nuestros dias se llama cocktail, pero un cocktail dado siempre por la misma persona. Esta clase de "salón" es la obra de la mujer, es su dominio y ella lo dirige. Por ello se le llamará por el nombre de la dueña de la casa, como puede comprobarse en el que recogemos de Madame Geoffrin.

Mas los dibujos y pinturas de Lancre, Fragonard, St. Aubin,... nos manifiestan que los salones y su atmósfera evolucionan a lo largo del siglo. Aparecen tres épocas con sus correspondientes prototipos. En sus inicios la sociedad es familiar, hacia la mitad es época de galantería y placeres y, antes de la Revolución de 1789 , se diserta sobre filosofía o política.

Al principio, los salones tenian un ambiente pobre y pobre conversación. A partir de 1750 -sigue diciendo Gall ${ }^{3}$-, alcanza una autoridad que será el apogeo de su reinado en toda la historia de la sociedad francesa. La lengua cambia y la decoración también. Los muebles se aligeran, las

Comte de Ségur, Memoires, 1826. Estas últimas citas son tomadas de la "Memoire de $2^{e}$ cycle" I.N.T.D. "La répresentacition des écrivains en France, au XVIII" Siecle", de Evelyne BREJARD.

${ }^{8}$ La pintura galante francesa en el siglo XVIII. Breviarios. F.C.E. México, 1975, pág. 41

9 Op. cit. págs. $42-44$. 
ventanas se adornan con cortinas caprichosas, se posan amorcillos pintados encima de las puertas, los bustos se elevan sobre librerias y armarios.

Al final del siglo terminan los bailes y las conversaciones galantes. Se razona, se discute y se diserta. Las ideas que privan son las de los Enciclopedistas. De esta manera los Salones preparan directamente la Revolución Francesa.

Los Salones son una especie de universidad de la conversación. En ellos se instruye uno, adquiere el tono del siglo, y este "tono" existe principalmente en la conversación. En el siglo XVIII se escribe y se habla mucho. L.a Correspondencia y las Memorias son una fuente certera para conocerlo profundamente.

En 1725 el salón cambia de sitio y pasa de la Gran Galeria del Louvre (lugar inicialmente elegido) al Salón Cuadrado. La disposición de los cuadros tenian unas reglas precisas; por ejemplo, el del rey debia estar en el centro. Los expositores eran exclusivamente miembros de la Real Academia de pintura y escultura, aproximadamente unos cuarenta. El público que iba a verlo era abundante, pues era gratuito.

Diderot, sobre el Salón de 1763, comenta la diversidad de juicios de la multitud en él... La gente de mundo se fija en los retratos de los que allí están presentes y no en los temas. Los hombres de letras, por el contrario, pasan rápidamente por los retratos y prestan su atención a las grandes composiciones.

Sus catálogos o libretos se presentan en un volumen en octavo y de unas veinte páginas. Comenzaba con un Prefacio, al que seguia la descripción de las obras expuestas. Para mayor facilidad las obras estaban numeradas en el libreto y en el cuadro.

Como, muchas veces, exponer en el Salón era muy peligroso porque las criticas afloraban con prontitud y las negativas en la recepción de obras exasperaba a los artistas, en 1723 se pensó renunciar a los Salones, pero, no obstante, se continúa.

Estas reuniones son el principal acontecimiento artístico de esta época y su reflejo.

Las obras que tenemos recogen dos momentos diferentes de los salones: el de las exposiciones artísticas, tan multitudinariamente concurridas, y la convocatoria al tipo de "fiestas galantes" regentadas por una mujer o formadas en su derredor. En el primer apartado se clasifican «Musée. Exposition" de Naudet (archivo Giraudon, Paris) y "Lauda-Conatum. Exposition au Salon du Louvre en 1787» (Gabinete de Estampas, Biblioteca Nacional de París), grabado por Martini, que se exhibió en la exposición de Diderot. 
Al momento festivo alude la litografía de Lemonnier (Biblioteca Nacional de París), titulada "Siglo de Luis XV" o "Une soirée chez Madame Geoffrin, en 1755", cuyo lienzo original se conserva en el Museo del Palacio de la Malmaison con el titulo de «Primera lectura en casa de Mme. Geoffrin en 1755". El lienzo, pintado en 1814 para la Galeria de la Emperatriz Josefina representa una reunión ideal de personajes célebres del siglo XVIII, como d'Alembert, Buffon, Diderot, Helvetius, Rousseau...

En torno a estos encuentros recordamos el siguiente comentario de Marmontel ${ }^{10}$ : "Numerosos escritores del siglo XVII han elegido "permanecer o asirse a este medio" tales como Montesquieu, Voltaire, al menos hasta 1750, Marivaux, D'Alembert. Es la época del "reinado de Mme. Goeffrini"».

"Madame Geoffrin habia fundado en su casa dos comidas; una (el lunes) para los artistas, la otra (el miércoles) para las gentes de letras... De esta sociedad, el hombre más alegre, el más animado, el más divertido en su alegría era D'Alembert...

Marivaux hubiera deseado mucho tener también este humor jovial, pero él tenia siempre en su cabeza un asunto que le preocupaba y le daba un aire inquieto...

Helvetius, preocupado de su ambición de celebridad literaria, nos llegaba con la cabeza aún enfrascada en su trabajo de la mañana. No habia un hombre mejor, liberal, generoso sin fasto y benéfico, porque él era bueno...".

Maurice Serullaz afirma que «Madame Geoffrin temia la petulancia de Diderot, su osadía, sus opiniones, aumentando, cuando él estaba eufórico, por una elocuencia fogosa e irresistible. Esta gesticulación era tan conocida que se acusaba a Diderot de que, en la mesa, se apoderaba de los brazos de sus contiguos, de no cesar de hablar y no menos de comer con ei mayor apetito".

Y en el Billete dirigido a Madame Geoffrin por la emperatriz Catalina II de Rusia leemos: "Vuestro Diderot es un hombre muy extraordinario, yo no acabo mis conversaciones con él sin tener las piernas magulladas y totalmente negras, me he visto obligada a poner una mesa entre él y yo para ponerme y asimismo a mis miembros al abrigo de su gesticulación".

Una nueva versión de este tema nos dejó Françis Boucher en "Una lectura de D'Alembert en el Salón de Mme. de Geoffrin». Quizás encargada

10 La Société littéraire du dix-huitième siècle. (Introducción de Maurice Languereau). Paris. H. Gautier, 1893. 
como homenaje a la constancia de la relación de esta noble mecenas con la Enciclopedia francesa a la que tanta protección pecuniaria otorgó.

Un eslabón intermedio entre los Salones y las asambleas de los Enciclopedistas lo constituye el "Festín del poeta Pirón con sus amigos Vadé y Collé", poeta festivo, pintado por Etienne Jeaurat (Museo del Louvre), en el que el aire jocoso es efectivamente el dominante.

En conmemoración de la figura de los Enciclopedistas, si bien no de tono revolucionario, son los grabados que comentamos a continuación.

Múltiples fueron los retratos que inmortalizaban a Voltaire, Diderot y tantos otros.

Acompañado de una innumerable asamblea de literatos, que lo aclaman, contemplamos a Voltaire en el momento de su "coronación en la Comedia Francesa" (dibujo a pluma de Gabriel de Saint-Aubin, en la Sala de Estampas de la Biblioteca Nacional de Paris y en el Chaucer, sobre una composición de Moreau), o "Coronado por comediantes franceses, el 30 de marzo de 1778" (Biblioteca N., Paris).

En «El genio de Voltaire y Rousseau conduce a estos célebres escritores al templo de la gloria y de la Inmortalidad" (Gabinete de Estampas de la Biblioteca Nacional de Paris), posterior a 1778, vemos a estos dos enciclopedistas, vistiendo la moda de su siglo y portando los atributos que los identifican -el libro de la Enríada y sus Pensamientos filosóficos, Voltaire, y unas flores y otros libros, quizás El Emilio, expresando el amor a la naturaleza cultivado por Rousseau-. La antorcha y las dos coronas de victoria, que porta el Genio, alude a su triunfo y al reconocimiento que la patria les otorga. Lejos, a sus espaldas, quedan Notre Dame y las agujas de la Santa Capilla. Frente a ellos se eleva el templo de la Inmortalidad, de líneas clásicas, significando, quizás, según la idea de Baudelaire, la eternidad frente a la fugacidad de lo moderno.

No siempre reinó la cordialidad entre estos dos escritores filósofos Voltaire y Rousseau, como lo muestra el grabado anónimo de la Biblioteca Nacional de Paris, en el que, según la glosa que lo comenta, se baten en denodado duelo, increpándose en términos tan grotescos e irrisorios como los siguientes:

"Tú, que quieres usurpar el cetro del Parnaso, que contra mis escritos hablas con audacia, Sobre ti mis maldiciones, estos puños me vengarán,... Atacarme sobre tus pies! oh! buen Dios! qué dirán los cuadrúpedos tus compañeros, 
Viéndote, los humanos, tomar tales modales? pero, la espada en el costado, se bate como mozo de cuerda!... por qué no la utilizas? los brocados te causan alarma? Un sabio, si tú lo eres, no se aparta jamás de las leyes de la naturaleza, y nuestros puños son sus armas".

El encuentro tiene lugar en plena naturaleza, sobre un frondoso árbol de fondo y unos macizos vegetales, abiertos por repetidos arcos, que le prestan su ritmo y movimiento. Distanciados éstos en primer término acogen a los dos protagonistas, mientras parecen confluir en la lejania como, en su profundidad, el espiritu de ambos pensadores.

No menos laudatorio es el grabado en color, que une a Voltaire, Rou sseau y Francklin bajo el lema o el título de "La antorcha del Universo". Los representa de medio cuerpo y en un círculo, como si fuese un ex-libris o la matriz de una medalla.

En un rato de solaz sorprendemos a "Voltaire jugando a las damas con el Padre Adam" (Grabado de Hubber, Biblioteca Nacional de Paris). La escena se desarrolla en un amplio salón, de los usuales en esta época. Sin embargo, la adecuación de su mobiliario no es perfecta ya que aúna la línea del estilo Luis XVI en hogar y molduras del vano de la puerta con la silueta del de Luis XV, o al menos de transición, de mesa y sillones. EI mismo eclecticismo se observa en la indumentaria del filósofo y su amigo, el jesuita y profesor de Humanidades Antonio Adam. Voltaire cubre su cabeza con el bonete que solía, frente al "Père Adam" que lleva tricornio. Los jugadores, sentados ante la mesa, atentos al tablero de ajedrez, permanecen, con sus acompañantes, ausentes del idilio amoroso del que goza una pareja, en la habitación contigua, y el que una cortina, indiscretamente recogida, desvela. Cabe preguntarse ante el detalle de la puerta abierta al fondo, si Huber quiso contrastar la frialdad de la razón, propia del siglo XVIII, frente al triunfo del sentimiento, que con el prerromanticismo, a fines de este mismo siglo, comienza a manifestarse. Quizás simplemente se sirvió, como tantas veces durante el barroco, del vano y claridad de una puerta de fondo para dar mayor amplitud y suntuosidad a la escena.

De nuevo de la mano de Huber (grabado del Museo de Carnavalet, de Paris) observamos a "estos padres de la patria" en una "Reunión (que otros han llamado comida) de los filósofos". A ella asisten Voltaire, el Padre Adam, el Abad Mauri, D'Alembert, Condorcet, Diderot y Laharpe. Esta obra, como la anterior, luce un dibujo preciso y destaca entre muchas por su encanto, espaciosidad y animada vivacidad.

Como sintesis de estas dos últimas obras parece ser el dibujo de Kretz (grabado por Badoureau) de “El Café Procope en el siglo XVIII. Reu- 
nión de Enciclopedistas". En la composición se distinguen tres grupos de figuras cada una con diferente actividad, propio de lo habitual en un café. Mientras unos juegan y otros hablan, un tercer grupo da lectura a algún artículo de próxima aparición. El espacio está perfectamente logrado; la movilidad en los gestos y figuras. Se observa la elegancia en el diseño y en la decoración interior.

Queremos subrayar el diferente trato que conceden los artistas a las figuras de Voltaire y Diderot en las obras que presentamos.

A Diderot se le magnifica y se le considera. Se le presenta haciendo "Una lectura" en su propia casa, en la evocación histórica pintada por Ernest Meissonier en 1850, y grabada por Mongin. Existe emoción en el ambiente, concentración en la lectura. Nada trivial. Ni un accesorio que distraiga. Hacia él se dirigen todas las miradas. Se han cuidado todos los detalles en medio de una gran sencillez -su gran biblioteca, el gesto declamatorio de la mano,...-. La pintura parece la grabación en color de la descripción que Grimm, su amigo y defensor, hace de él (Correspondencia literaria, 1 de octubre de 1763).

Luis Michel van Loo nos retrata igualmente a Diderot en 1767 en el momento álgido de su creación literaria. Es un retrato psicológico y poético. Más que sus rasgos se adivina su alma, se contempla su espíritu abierto y atento a la inspiración. El ademán de su mano derecha dispuesta a escribir y con la mirada y su izquierda parecen querer apresar el mensaje que ie fuere transmitido. (Este retrato fue grabado por Eugenio Lacogne.)

Contrariamente, a Voltaire no se le respeta su intimidad, se le sorprende en el momento de levantarse cualquier mañana de su vida en su palacio de Ferney.

La escena se desarrolla en una pequeña habitación con todo el mobiliario y decoración de época, que le prestan cierto encanto. Se dan una serie de circunstancias por las que parece que el autor ha querido narrarnos gran parte de la vida de Voltaire y sus connotaciones. Una mezcla extraña de ternura, cordialidad, soledad y odio.

Al llamarlo el filósofo de Ferney (en el titulo del grabado) nos alude al lugar de su residencia habitual. Esta aldea, próxima a Suiza, de la que el escritor filósofo en 1758 adquirió el dominio con su palacio, que conserva aún recuerdos suyos, y que habitó hasta su muerte en 1778. La ambientación y decoración hemos dicho es de época, mas, de forma insólita, observamos que el muro se decora con el retrato de Freron, su más encarnizado enemigo. El crítico Elias Catalina Freron, redactor del Año literario escribió Observaciones sobre los escritos modernos en los que desacredita a los enciclopedistas, especialmente a Voltaire. Éste se venga a cambio 
caricaturizándole ridiculamente en varias de sus obras teatrales y le dirigió un libelo "Anécdotas sobre Freron" en el que se acumulaban los más atroces cargos contra el desventurado crítico.

Y esta relación "amistosa" queda subrayada por los versos que dicta a su lacayo y que el autor cuida de transcribir al pie del grabado.

Apenas tres retazos de la actividad española en este siglo nos presentan las litografías de Serra-Vidal. La investigación a través de los archivos españoles, en el reinado de Fernando VI, se personifica en las figuras responsables de ella -el docto jesuita Andrés Burriel y el profesor de la Universidad de Salamanca, doctor Pérez Bayer-. Nuestras relaciones exteriores en sentido religioso nos las simboliza la actividad del cardenal Portocarrero al frente de una Junta de Teólogos para dilucidar la solución de una desavenencia entre España y la Santa Sede. Mientras las relaciones políticas a nivel internacional se ven defendidas ante los Estados Generales en La Haya por el marqués de Monteleón, embajador de España en Londres.

En los tres es claro el elevado nivel social y la relevancia lograda por los escritores e intelectuales, así como la ambientación suntuosa y gestos grandilocuentes caracteristicos de la época.

En Francia, la caricatura, exagerando los "signos distintivos" de las personas representadas, deforma sus cuerpos y sus rostros y, sin embargo, esta operación tiene por fin acrecer la evidencia de su identidad.

Desde entonces la pintura y la escultura quieren intentar hallar otros criterios de parecido que los de la estricta fidelidad en los trazos del rostro y del cuerpo. Intentan hallar y traducir un parecido encontrado más allá del aspecto psicológico del modelo, el trazo caracteristico de la personalidad, trazo que la define más aún que los mismos rasgos físicos.

Las manifestaciones artísticas y parapictóricas, que hemos encontrado, nos confirman que coexisten diferentes técnicas: la pintura de retratos de gran formato -inmortalizando el encuentro de los poetas-, los grabados caricaturescos del sabor e intencionalidad más variopintos y los montajes fotográficos al uso.

Los montajes fotográficos o las representaciones al estilo de tales, parecen reservados para plasmar a los escritores que ocuparon cargos políticos, tales como los del Gobierno Provisional francés de la República o su Poder ejecutivo de la misma época, en el que aparecen Lamartine, Ledru-Rollin, Arago, Marie y Garnier-Pagés. Alunque a veces, como en el grabado de Llanta, se conceda a "Los artistas contemporáneos".

Los grabados nos caracterizan las actitudes, vivencias y sociedad de esta época. 
A la llegada del correo asistimos en "La chambre littéraire" (grabado del archivo Giraudon), donde los lectores, unidos en torno a una mesa oval, se individualizan absortos por las novedades que acontecen.

La reacción de los franceses contra su propia tradición clásica, que es uno de los signos de su romanticismo, nos viene dada por una serie de caricaturas muy sabrosas. ("Les romantiques chassis du Temple», del Museo de V. Hugo).

La figura de Víctor Hugo queda magnificada en toda una serie de versiones, que podrian ser meramente el eco de la fama de que gozó o del homenaje popular que Francia le rindió, al que se sumaron Europa y América.

En el "Libro de los cuatrocientes autores" lo vemos contemplar sentado (desde el ángulo inferior izquierdo de la composición) las tareas de sus colegas, o encabezando el "Panteón caricaturesco de los escritores célebres".

Con el mismo gesto de primacía y magisterio, sentado en su sillón, dirige el diálogo literario con Viennet, Scribe y Alfonso Karr. O, a su mismo nivel, con Sué, Dumas y Balzac. Asi como su Salón literario o al frente del desfile de "Le carnaval des journaux", publicado en Le Carillon (10 de febrero de 1844).

El pensamiento y las tendencias literarias del siglo XIX se podrían sintetizar en las representaciones que aportamos en las siguientes: el liberalismo alemán y su proyección, en Hegel y Nietzsche; el romanticismo y su preludio, en Goethe y Chateaubriand, y el naturalismo-realismo, en Zola y Benito Pérez Galdós.

El retrato ha tenido en Francia, de forma semejante a España, una larga y rica historia y, principalmente desde $1870^{11}$.

La caricatura, las ediciones populares ilustradas, un poco más tarde el affiche, que entra en su edad adulta con Toulouse-Lautrec, conocen un desarrollo prodigioso y durante los treinta años ultimos del siglo XIX van a multiplicarse los periódicos satíricos ilustrados. El perfeccionamiento de las técnicas de impresión, el grabado y la fotografía han contribuido a ello en gran medida.

En el retrato oficial o mundano aparecia la voluntad de hacer resurgir la elegancia del modelo y su situación social. Mas las imágenes que ahora surgen dan una nueva vida a las viejas convenciones, dando a las cabezas

1 "Visages et portraits de Manet à Matisse". Cahiers. Musée d'Art et d'Essai. Paris, n 7 XI, 1981 . 
una expresión que permite traducir los sentimientos, los caracteres y los temperamentos según las líneas del rostro.

Si en épocas anteriores el accesorio confiere al retrato una significación "suplementaria" que traspasa la simple identificación nominal para indicar una "cualidad", este "complemento de significación" se encuentra desplazado de distintas maneras a fines del siglo XIX.

Con carácter más social y de recreo literario aparecen los escritores en torno a Madame de Girardin en el «Té artístico animado con grandes hombres", en el que el lujoso interior, los trajes elegantes y la relación entre los componentes tanto dicen en relación con la obra a la que hacemos referencia.

Solemnes fueron las fiestas y su plasmación artística con motivo de la "Recepción de Víctor Hugo en la Academia Francesa en 1841" (dibujo en color de Vogel, en el Museo de V. Hugo) y la "Cena ofrecida por los representantes de la Prensa en el cincuenta aniversario de 'Hernani'" (dibujo de Huberto Clerger), que marcó un hito de tal relevancia en el teatro fraricés por su carácter anticlásico.

Múltiples son las caricaturas halladas en las que las escenas y personajes literarios se nos presentan al estilo de las «bandas dibujadas nacientes". En todas ellas la supremacia y papel directriz de Víctor Hugo aparece de modo indiscutible.

Con gesto hosco y suficiencia contempla el ascenso de sus seguidores en “El Panteón del diablo en Paris" (o «La poesía, la filosofía y la literatura").

En el "Gran camino de la posterioridad" cabalga sobre una quimera portando el estandarte anticlásico con la inscripción que simboliza la nueva estética revolucionaria "lo feo es bello".

Y, finalmente, en "... Par Pilotell» contempla airado, como un Titán, los pigmeos y deformes humanos que intentan dirigirse al Instituto de Francia en cuyo tímpano ruinoso se lee en italiano: «Dejad toda esperanzalos que aqui entrais", comparándolo o recordando la inscripción que Dante coloca a la entrada del Infierno en su Divina Comedia.

En todas estas producciones artísticas - dibujos, grabados o pinturas aparece Victor Hugo con el mismo semblante característico que nos describió Castelar y creemos su mejor retrato: “El rostro de Víctor Hugo es, como su espíritu, iluminado. La cabeza, grande y esférica; la frente, ancha como un cielo destinado a recibir muchos astros; los ojos, pequeños, pero profundos, como los abismos de su pensamiento; la nariz, aguileña; la barba, blanca con la nieve de los años; toda su figura acusa las cualidades 
culminantes de su espiritu: la fuerza atlética, la energía indomable; esa complexión de combatiente que le ha dado una serenidad olimpica en medio de las más rudas campañas de su vida...”.

Aún más pretencioso resulta «El Panteón Nadar» en su versión original y en la de Prime du Figaro-Panthéon Nadar. (Ambos en la Biblioteca Nacional de París). Bajo su firma: “Nadar 1854», se puede leer la frase manuscrita: "(Nadar) que está muy contento de terminarlo", y como dedicatoria: «Al Señor que yo siento de veras y de antemano no conocer y que el octavo día de la tercera luna del año $3607^{12}$ locamente se fue en busca de este ejemplar ya inencontrable para comprarlo a precio de oro y del cual no se podrá privar para su gran trabajo sobre las figuras históricas del siglo $X \mid X$ ".

Según Jean-Françoi Bory ${ }^{13}$, Nadar ${ }^{14}$ tenía la intención de realizar la litografía que reuniera todos los contemporáneos célebres, tras la publicación de una serie de caricaturas de contemporáneos acompañados de noticias biográficas salpicadas de humor.

La página hebdomedaria, intitulada La lanterne magique, alegra a los lectores del Journal pour rire desde enero de 1852. A medida que los retratos se van haciendo, la idea se precisa, prevé una serie de cuatro hojas representando hombres de letras, dramaturgos, pintores y músicos, en un total de 249 personajes.

Anunciado en septiembre de 1852 en el periódico de Villedemil y de los Goncourt, L'Eclair, este programa de tan gran envergadura es acogido como la novedad que no puede faltar.

Millaud, el padre de Petit journal, entra un día en casa del artista y le propone comprarle su rica colección y le da 15.000 francos para ayudarle a terminar su obra (Commerson en Les Binettes contemporaines, Millaud, 1854).

Nadar se ayudaba en sus dibujos de las fotografías, que le permitian avanzar. "La fotografía que termina de "nacer" -dice él- ofrecia, al menos a mi impaciencia, este modo de no fatigar largo tiempo la prestación de los modelos, y, al mismo tiempo, abría para él unos caminos insoñables...»"

12 Pensamcs que el autor ha puesto la fecha que constituye el doble de años con relación al que él lo terminó.

${ }^{13}$ Escribe las Introducciones, notas y comentarios del T.2 de NADAR, Dessins et écrits. Paris. Arthur Hubschmid, 1979, págs. 891-892.

${ }_{14}$ Félix Tournachon, literato, pintor y auronauta francés, llamado NADAR.

is Nadar. Quand j'etals photographe. Paris, 1900. 
Una ley imperial prohibia la publicación de caricaturas sin la autorización estricta de la "victima". Por ello, una prolongada correspondencia retrasa dos o tres años la elaboración de la colosal litografia. A comienzos de 1854 , el trabajo preparatorio toca a su fin. Una campaña publicitaria eficaz (prospectos, boletines de suscripción, anuncios en los periódicos) es llevada a cabo, y desde comienzo de marzo de ese año, el primer Panthéon sale de la imprenta de Lemercier.

Se trata de una gran litografía de 115 por $84 \mathrm{~cm}$. Todos los marchands de vistas de Paris ofrecen sus vitrinas y lo exponen de forma destacada. Toda la prensa habla de ello. Una locura colectiva invade al públi$\mathrm{co}$, que quiere poseerlo. Sin embargo, Nadar apenas cubre gastos, a pesar de la generosa participación de Moisés Millaud.

Ante esto, Nadar renuncia a las otras hojas previstas. Un segundo Panthéon, por contrato con Le Figaro es publicado. Su título es ligeramente diferente: Prime du Figaro, Panthéon Nadar. La misma composición en cortejo, el mismo formato, vuelve a tomar los mismos personajes centrales, resultando una litografía poco distinta de la primera. Sin embargo, esto dio a Nadar la ocasión de introducir a sus célebres contemporáneos, frustrados por no figurar en el primero. Entre ellos podemos ver a Delacroix, Doré, Monnier, Halévy, Meyerbeer, Rossini, Alfred Adam, Auber, Berlioz, Offenbach. La identificación de los representados en el orden dado por Nadar es la que damos en nota $\left(^{*}\right)$.

\footnotetext{
1 Georges Sand

2 Honore de Balzac

3 De Chateaubriand

4 Fréderic Soulié

5 Paut-Louis Courier

6 Charles Nodies

7 Baron Taylor

8 Victor Hugo

9 De Lamartine

10 De Beranger

11 De Lamennais

12 Henri Heine

13 Leon Gozlan

14 Alfred de Musset

15 Alfred de Vigny

16 Gerard de Nerval

17 Felix Pyat

18 Méry

19 Auguste Luchet

20 Paul de Kock

21 Jules Sandeau

22 Alexandre Dumas

23 Alexandre Dumas fils

24 Auguste Maquet

25 Marquis de Belloy

26 Nestor Roqueplan

27 Marquis de Chenevieres

28 Roger de Beauvorr

29 Alphonse Karr
}

\author{
30 Leon Gatayes \\ 31 Pierre Dupont \\ 32 Gustave Matheu \\ 33 Jules Lecomte \\ 34 E. Marco-Saint-Hilaire \\ 35 Jules Lacroix \\ 36 Paul Lacroix \\ 37 Hippolyte Lucas \\ 38 Emile Souvestre \\ 39 Paul Féval \\ 40 Theodore de Banville \\ 41 Henry Murger \\ 42 Auguste Vacquerie \\ 43 Paul Meurice \\ 44 Eugene Sue \\ 45 Edmond Texier \\ 46 Amedée Achard \\ 47 Jules Janin \\ 48 Theophile Gautier \\ 49 Jules de Premaray \\ 50 Auguste Lireux \\ 51 Paul de Saint-Victor \\ 52 De Mathareal de Fiennes \\ 53 Charles Philipon \\ 54 Louis Huart \\ 55 Taxile Delord \\ 56 Clement Caraguel \\ 57 Hyppolite Rolle \\ 58 Gaiffe
}

59 Edouard Thierry

60 Louis Desnoyers

61 Commerson

62 Vachette

63 Hippolyte Babou

64 Gustave Planche

65 Theophile Thore

66 Albert de la Fizelière

$67 \mathrm{~J}$ J. Arnoux

68 Delécluze

69 Pierre Petroz

70 Cnarles Tillot

71 Hetzel (J.B. Stahl)

72 Eugene Pelletan

73 A. Toussene!

74 Altaroche

75 Adam Mickiewietz

76 Edgard Quinet

77 Michelet

78 Alberic Second

79 Louis Lurine

80 Philarète Chasles

81 Louis Viardot

82 Etienne Arago

83 Louis Blanc

84 Cnarles Blanc

85 Villiaume

86 Ledru Rollin

87 Leon Fauche 
En pintura son varias las obras que, como "el Taller" de Courbet, nos reproducen el encuentro de artistas y literatos. Caminando aguas arriba de la historia observamos que de 1900 a 1901 es el «Homenaje a Cézanne" de Maurice Deris; en años sucesivos Fantin-Latour trata el tema con entusiasmo y reiteración. Le sirven de pretexto "Coin de table" de 1872, el "Taller de Battignoles", de 1870, que tanto recuerda el de Courbet, y el "Homenaje a Delacroix", de 1864-1865.

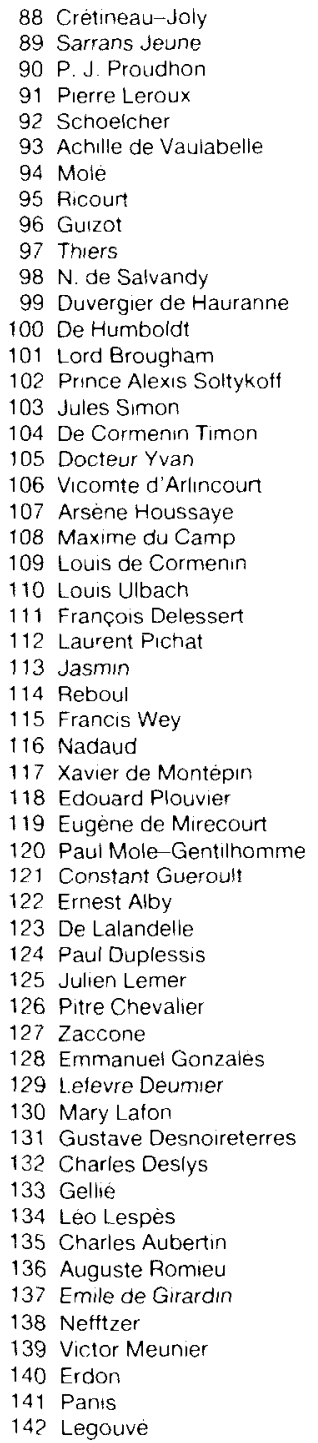

143 Mme H. Becker Stowe

144 Mme Charles Reybaud

145 Mme A. Tastu

146 Mme Desbordes Valmore

147 Comtesse d'Agout

148 Anaıs Segalaso

149 Louise Collet

150 Mme de Girardin

151 Clemence Robert

152 Mme Esquiros

153 Blaise des Vosges

154 Felix Solar

155 Eugene Forcade

156 Paul Mantz

157 Leon Plee

158 Gustave D'Alaux

159 Havin

$160 \mathrm{E}$. de Labedolliere

161 Louis Jourdan

162 Emile Pages (Bergeron)

163 Lefrançols

164 Alexandre Weilt

165 Pol Millaud

$166 \mathrm{~J}$. Mirés

167 Leon Paillet

168 Xavier Eyma

169 Leopold Duras

170 Theodore Pelloquet

171 Turgan

172 Eugene de Stadler

173 Dutaca

174 Falempin

175 Félix Mornand

176 Sylvain Saint-Etienne

177 Busoni

178 Pierre Bernard

179 Revoil

180 Marie Escudier

181 Léon Escudier

$182 \times \times \times$

183 De Villemessant

184 Rene de Rovigo

185 De Coetlogon

186 Dumont

187 Eugene Bareste

188 Achille Denis

189 Charles Hiltbrunner

190 Couailnac

191 Emile Badoche

192 Eugene Chapus

193 Gustave Bourdin

194 Leroy

195 André Thomas

196 Pierre Lachambaudie
197 Viennet

198 Marquis de Varennes

199 Leon Noel

200 Lèopold Léclanche

201 Chaalons D'Argé

202 Etienne Enault

203 Charles Asselıneau

204 Cretet

205 Benjamin Tilleul

206 Charles Hugo

207 Françoıs-Victor Hugo

208 Charles Baudelaire

209 Vicomte Ponson du Terral

210 Charles Bataille

211 Champfleury

212 Monselet

213 Armand Baschet

214 Ant. Fauchery

215 Fernand Desnoyers

216 Xavier Aubryet

217 De Barenton

218 Paul Jullerat

219 Henrı Delaage

220 Judicıs

221 Edmond de Goncourt

222 Jules de Goncourt

223 Charles Emmanuel

224 Claudon

225 Fertiautt

226 Paul Cère

227 Maurin

228 Jules Viard

229 Charles Gilles

230 Altred d'Alembert

231 Moineaux

232 Antonio Watripon

233 De Balathier de Bragelonne

234 Georges Bell

235 Benjamın Gastineau

236 Andre de Goy

237 Barre

238 Robertson

239 Eugène Furpille

240 Edouard Hanquet

241 Dondey-Dupre

242. Charles vincent

243 Aurelien Chol

244 Henri Nicolle

245 Prarond

246 Levavasseur

247 Charles Barbara

248 Desquiron Saint-Aignan

249 Stanisias Godefroy 
Matiz diferente tiene el ensayo del tema realizado por Manet, dos o tres años antes. En “Música en Tullerías", de 1862, obra que enlaza en su continuidad y aproximación a la indiscutida y citada creación de Courbet, en su "Taller del artista", de 1855, Manet recompensa el valor de lo instantáneo traspasando al acto artístico la experiencia vivida recientemente, por ello los personajes no son anónimos, se reconocen bajo sus trazos a parisinos célebres-Teófilo Gautier, el compositor Offenbach, el barón Taylor, Champfleury, el periodista Aurélien Achool, el pintor Pantin-Latour, el mismo Baudelaire, Zacarias Astruc y Eugenio Manet, su hermano.

Paradójicamente, la pintura de Courbet, tan preocupado por la realidad, para quien la pintura debia siempre reproducir objetos reales y existentes, termina por ser alegórica.

En Manet no hay vestigios sentimentales, que delaten una intención oscura reprimida y, en él, el cuadro llega a ser documento sin haberse propuesto ser testigo o testimonio del presente ${ }^{16}$.

El comentario del cuadro nos viene dado por el mismo artista en una carta dirigida a su amigo Bruyas, mientras lo está realizando, en diciembre de 1854. La alegoría que él nos plasma es la «epifanía de la pintura sobre la tela", de la cual son testigos sus amigos Baudelaire, Bruyas, Champfleury... A la derecha se sitúan personajes, sus amigos, que simbolizan distintos aspectos del arte: Baudelaire, leyendo un libro -la Poesía-, Bruyas -el Mecenazgo-, Promayet -la Música-, Bucho, Champfleury, Proudhon..., y otros ${ }^{17}$.

Chateaubriand y otros literatos protagonizaron el romanticismo de corte tradicional, frente al de carácter liberal capitaneado por Victor Hugo. Esta faceta literaria primera queda también, como la liberal, reflejada en el arte y con las mismas técnicas que las anteriores.

En torno a Chateaubriand, situados como en un montaje fotográfico, se congregan "los artistas contemporáneos»-Delavigne, Hugo, Béranger, Dumas, Lemercier, de Lamartine y Etienne".

Mayores pretensiones manifiestan la pintura anónima que inmortalizó la "Tertulia en torno a Madame Ancelot, en 1841", y la de "Andrieux haciendo una lectura en la Comedia francesa", hacia 1830, por Heim, cuadro que se expuso en el Salón de 1847 y hoy se conserva en el Museo de Versalles. El escenario de ambos es visiblemente romántico y la ambientación la propia de los Salones de la época.

La obra de Heim es un cuadro retrospectivo, agrupando para una lectura ficticia a los principales escritores de 1830, clásicos y románticos.

16 Julian Mereuta, Edouard Manet. Paris, 1975, pág. 20

17 Sandra Pinto, Courbet. Barcelona. Toray, 1972, pág. 15, 17, 34. 
Andrieux está de pie ante la mesa y tiene un manuscrito. Arnault y BaourLormian están sentados a ambos lados. Los otros personajes representados son, comenzando por la derecha del espectador: Dumas, Michelot, Firmin, Victor Hugo, Scribe, Mélesville, Lebrun, Ancelot, Antony Béraud, Casimir Delavigne, Viennet, Népomucène Lemercier, Empis, Mme. de Bawr, Mazères, Chateaubriand, Charles Nodier, Pigault-Lebrun, Etienne, Jouy, le baron Guiraud, Liadières, Nanteuil, Arnault fils, Frédéric Soulié, Jules Lefèvre, le comte Alfred de Vigny, $\mathrm{M}^{\text {me }}$ Duchesnois, Samson, Soumet, $M^{m e}$ Ancelot, Emmanuel Dupaty, Briffaut, le baron Taylor, Léon Halévy, Emile Deschamps, Planard, M"e Mars, Alexandre Duval, de Laville, d'Epagny, Casimir Bonjour.

El siglo XIX español ofrece creaciones paralelas a las de Francia -lecturas (más llamadas entre nosotros Tertulias), "montajes fotográficos" de carácter literario-político ("Los cuatro presidentes de la I República") y representaciones de los "cafés de artistas"-.

El que tiene el honor reconocido de ser la primera creación de grupo de escritores, como impagable crónica del tiempo, es la de Antonio María Esquivel, que posee el Museo Nacional de Arte Moderno de Madrid, precedida por otra obra suya, que custodia el Museo Romántico como legado del Prado, que permanece inacabada, como si hubiera querido hacer en ella el ensayo de su definitiva lectura de poetas.

Resultan ambas pinturas poco atrayentes por la teakralidad de la composición y la carencia de cohesión espiritual de los personajes con el momento en que están viviendo. $Y$ su valor es extra pictórico: reside en su condición de documento útil para la conocimiento de la época.

El primero de estos lienzos, "Ventura de la Vega leyendo una obra entre los autores de la época", nos muestra al citado escritor en el escenario del Teatro Príncipe, leyendo el original de alguna comedia -«El hombre de mundo", según Guerrero Lovillo ${ }^{18}$ - a la compañía titular.

Un año más tarde, en 1846, Esquivel -escribe Gaya Nuño ${ }^{19}$ - quiso dejar un retrato elocuente de lo que fuera el romanticismo, de quiénes, entre los escritores, eran imprescindibles para la visión verídica que de tal movimiento en España tendrian que formarse los investigadores de las corrientes intelectuales.

18 Antonio Maria Esquivel. Madrid. C.S.J.C., 1957, lám. 47, págs. 34-35.

19 Arte del siglo XIX. Ars Hispaniae. T. XIX. págs. 34-36. 
La composición representa al poeta Zorrilla en el centro izquierda, dando lectura de sus obras a escritores contemporáneos, todos ellos reunidos en el estudio del propio Esquivel, quien, por un momento, suspende la pintura de un cuadro. Se congregan cuarenta y cuatro, de los cuales, dos -el Duque de Rivas y José de Espronceda- se hallan retratados en sendos lienzos que penden del muro por ser personajes pertenecientes ya al pasado. La identificación de cada uno de estos personajes es posible gracias a los estudios de Eusebio Blasco ${ }^{20}$.

Coetáneas son también las pinturas de Leonardo Alenza, hoy perdidas, de "Las Ciencias y las Letras Ilorando la muerte de Fernando VII", de 1833, y las que decoraron el "Café Levante" también anteriores a 1845. Sobre la belleza de las pinturas del café madrileño podemos juzgar a partir de los dibujos preliminares que hoy se custodian en el Museo Municipal, y las escenas de café conservadas en el Museo Lázaro Galdiano, al parecer, posibles bocetos de esta misma creación.

En la ejecutoria de los cafés literarios “Pombo" es el Caballero del Toisón de Oro, retratado al óleo y colocado sobre la chimenea de la aristocracia de los cafés, como un hidalgo a quien le sobran títulos para dejar a su descendencia.

Al “Café Comercial» fue durante tiempo César González-Ruano, pero sólo a escribir, a hora temprana, alternándolo con el "Café Gijón", donde solia acompañarse de Marino Gómez Santos.

El momento de la poesía ultraísta pasa por los divanes del «Café Platerías", a donde van Lorca, Alberti y Eugenio Montes. En el "Lisboa» se reúnen los cómicos tras la función de noche. Unamuno acude al "Regina" con el cuello de la camisa blanca sacado por encima del chaleco, donde solía leer en voz alta, en una sola sesión, un libro suyo, inédito, sin admitir comentarios ni disculpas para ausentarse.

Valle-Inclán disparataba en "La Granja El Henar», peinándose entretanto las barbas con los dedos.

Hacia 1928, el dueño del "Café Gijón" abrió el café de Recoletos. pronto sede de la tertulia fundada por César González-Ruano con Jardiel Poncela, Rafael Duyos, etc., cuya crónica o eco de la tertulia era escrita por el fundador en la revista Gracia y Justicia con el título "Del Olimpo a la mesa del café».

Hacia 1934 la Tertulia inicia una activiadad que, por artística, queremos señalar. Este grupo de hombres de letras organiza sus «visitas de

20 Guerrero Lovillo, op. cit., págs. 35-36, lám. 48. 
arte" a los viejos lugares madrileños, que pronto iban a desaparecer o ser deteriorados.

Mientras, el primitivo "Gijón», un catetin burgués, guarda el recuerdo de sus visitantes -los Machado, Julio Romero de Torres, Rubén Dario, Galdós,...- en las caricaturas con que el dibujante Sirió cubrió la superficie de la mesa. Y alli permanecieron hasta que la implacable acción del tiempo los borró.

Aún debemos recordar "El Gato Negro", ámbito de la tertulia famosa de Benavente; el "Varela", rincón de Carrère, y el "Lyon d'Or", púlpito de don Eugenio D'Ors.

Vamos a detenernos en tres Tertulias como colofón de nuestro trabajo. Primeramente en la del "Café Pombo", que Solana inmortalizó en su lienzo, expuesto en el Salón de Otoño de 1920 y que fue colocado en la presidencia de fondo de la cripta abierta de dicho Café, el mismo autor nos lo comenta modestamente.

"Es un cuadro -escribe en el Epilogo de su España negra ${ }^{21}$ - a medio conseguir, y ahora, verdaderamente, siento el no haberle podido dar una forma más acertada y más decisiva. En el centro está nuestro amigo Ramón Gómez de la Serna, el más raro y original escritor de esta nueva generación. Está, pues, en pie y en actitud un poco oratoria: recio, efusivo y jovial, un tanto voluminoso, pero menos de lo que deseamos verle, para completar su gran semejanza con un Stendhal español o un nuevo Balzac de una época más moderna y menos retórica; cerca de él su cartera, esa buena amiga que siempre le acompaña, llena de pruebas de imprenta y dibujos que hace rápidamente para ilustrar sus escritos, son comentarios gráficos admirables y que dan un encanto más a los artículos que publica casi diariamente en La Tribuna y EI LiberaL.

"A su lado Bacarisse, Coll, Bartolozzi, Borrás, Bergamin, Abril y encima, el prodigioso espejo de Pombo, este espejo cinematográfico, cuya luna patinada cambia constantemente de expresión, unas veces nos sugiere ideas antiguas, nos transporta a la época de Larra; los viejos, con grandes levitones y las enormes chisteras, los fracs, las corbatas de muchas vueltas y los chalecos rameados, de los que cruzan las pesadas y largas cadenas de orc

"Pero este cuadro resulta pobre; faltan grandes artistas, ¿dónde están lturrino, los hermanos Zubiarre, Bagaria, Maeztu, Rusiñol, Romero Calvet, Victorio Macho? No puede dar idea niguna de su animación, de esas mesas que se van llenando de contertulios: Vighi, Espinosa, Llovet, Jiménez Aquino, Heras, Guillermo de Torre, Garza Rivera, Isaac del Vando-Villar, Pascual, Alcaide de Zafra, Pepe Argüelles y tantos otros."

Y. Solana, de Rafael Florez. Madrid. M.E.C. Colección Artistas Contemporáneos, 1974, págs. 26-27. 
Goñi, medio siglo después, hace otra interpretación del tema que, por menos conocida, es la que aportamos ${ }^{22}$.

El Café del "Lyon d'Or» era la sede de la tertulia -modelo de la postguerra-.

La integraban una serie de amigos que formaban un heterogéneo grupo unido por la inquietud por lo intelectual. En unos años oscuros, frios y estrechos, unos hombres cultos, famosos o inquietos se reúnen todas las noches en dicho café para mantener viva la hoguera de la conversación, la amistad y la literatura.

Esta tertulia integrada desde 1937 por José Maria de Cossio, Emilio García Gómez y Antonio Díaz-Cañabate celebraba sus encuentros en un café que pronto desapareció: el "Acuarium", del que pasaron al "Kutz", donde se les unió don Eugenio d'Ors. A poco se dieron cita en el café del "Lion d'Or», en el que la tertulia comenzó a incrementarse, ganó en animación y fama.

Esta tertulia ha tenido un cronista en uno de sus miembros -Antonio Días Cañabate ${ }^{23}$. Su narración es elegiaca, es la elegía de la tertulia que ha muerto, de una amistad colectiva que se ha dispersado. La tertulia del "Lion" era una hoguera de tres llamas: los toros, la literatura y las anécdotas. Todo ello resume bien la personalidad del gran animador de ella, José Maria Cossio.

Los toros son como continuidad del ser de España por encima de la gran quiebra de la guerra. La literatura como paraiso exento en años de dura y fea política. Las anécdotas como un humanismo, menor, como una manera de entender al hombre por lo pequeño, renunciando a las grandes ideas, entonces peligrosas.

Cuando la tertulia se incrementó figuraban como contertulios el doctor Oliver Pascual, Camón Aznar, Ignacio Zuloaga, Domingo Ortega, Eduardo Llosent Marañón, Sebastián Miranda, Edgar Neville con su humorismo a veces desgarrado, Regino Sainz de la Maza, Garcia Gómez, Eduardo Vicente, Labiaga, Antonio Diaz-Cañabate y algún otro.

El ingenio universalista de d'Ors se manifestaba siempre agudo y oportuno en una frase o en una digresión.

Tuvo diez años de duración, iniciándose en 1937 cuando Cossío escribia lo que habia de ser su gran obra de Los Toros.

Tomada de Tertulias y grupos literarios (Madrid, 1975) de Miguel Pérez Ferrero.

23 Historia de una tertulia. Madrid, Austral (38), 1978. Miguel Pérez Ferrerro, en Tertulias y grupos literarios (Madrid, 1975) le dedica un capitulo (págs. 105-112) con el dibujo de Goñi, que reproducimos. 
La interpretación artistica de este grupo poético nos la da Goñi, el pintor sordo, en su forma más habitual, con un sentido surrealista, fantasmagórico, acorde con las ideas que alumbraban la vida de las figuras responsables del grupo, en los cuales se resume su figuración como símbolo y compendio de esa vida nocturna, de cada dia, durante unos años difíciles para España. Todo el ambiente de ruina y restauración se intuye en el dibujo, asi como la esperanza certera que alienta hacia un futuro significada en esos ojos que «miran" por doquier.

Finalmente, el grupo poético “Alforjas para la poesía» tuvo en el pintor madrileño José Luis Morán su mejor cronista.

Este retrato es una de las muchas iniciativas felices de Conrado Blanco, ese burgalés a quien tanto deben todos cuantos en España aman o cultivan la poesia, que lo encargó al joven artista Morán.

Es un retrato plural de los poetas participantes en el grupo.

El ambiente, aunque no ninguno de los detalles de la composición, nos hace pensar por encima de todo en la Junta de la Compañia de Filipinas, esa impresionante obra de Goya, que José Luis Morán dice no haber visto y que, aunque la hubiese contemplado detenidamente, no le habria influido, dado que sus problemas eran otros. El chorro de luz roja que cae sobre el suelo del escenario, entre los poetas y los espectadores, hace que todos ellos constituyan un aro en torno a un fuego ideal, que sirve de centro no sólo formal, sino también cromático para el conjunto de la composición. Cada una de las figuras del fondo, al igual que acaece con las parejas de ancianos de "El pórtico de la gloria", parece dialogar con la contigua. Todo se enlaza así con todo, y a ello contribuye incluso el desgradado, raspado y entreverado de los fondos, de los que las figuras no parecen hallarse expelidas, sino ser más bien condensaciones de los mismos.

Paralelamente a sus virtudes plásticas, creemos será esta obra un documento de época, pero no en el aspecto arıecdótico, para recordarnos, pasados los siglos, cómo daban sus recitales nuestros poetas, sino en el más sagazmente introspectivo, en el que nos relata a través de sus expresiones, miradas y gestos y utilizando como complemento el ritmo de las formas y del color, cuáles eran sus preocupaciones en cuanto gremio todavía vivo, en medio de una comunidad que tiende a sindicarse por un ineludible imperativo de la evolución de la historia.

En suma, José Luis ha sido capaz de hacer una de esas obras que más tarde han de buscar los eruditos para ilustrar antologias y embellecer tratados de literatura. 
Del misıno modo que la tertulia del "Café Pombo" estuvo presidida por el cuadro en que Solana inmortalizó a los contertulios de Ramón Gómez de la Serna, en el vestíbulo del teatro Lara existe el lienzo testimonial de Morán en el que aparecen sentados en el escenario algunos de los poetas componentes de "Alforjas para la poesía" en torno a su fundador. $\mathrm{Ni}$ en uno ni en otro hubiera sido posible agrupar a todas las personalidades que desfilaron por la tertulia de la famosa botilleria ni en las innumerables sesiones poéticas de "Alforjas". Los pintores se han limitado, en ambos casos, a representar los elementos esenciales por más asiduos, con lo cual la intención queda cumplida en un resumen iconográfico ${ }^{24}$.

En el caso de "Alforjas", en el curso de sus treinta y cinco años de actuación, puede afirmarse que han participado desde Manuel Machado, Benavente y Marquina hasta los jóvenes que surgen de los premios y de las ediciones poéticas más prestigiosas. Un censo completo, actualizado, escapa a nuestro propósito, aunque la memoria nos acerca ahora nombres de poetas como Agustín de Foxá, Eugenio d'Ors, Eduardo Alonso, Felipe Sassone, Víctor de la Serna, José del Río Saínz, José Carlos de Luna, Tomás Borrás, César González Ruano, Guillermo Fernández Shaw, Rafael Sánchez Mazas, Manuel Sánchez Camargo, José Maria Souvirón, Federico Muelas, Manuel Dicenta, Pemán, Manuel Alcántara, José Garcia Nieto, Torcuato Luca de Tena, Gerardo Diego y un largo etcétera.

Para idear este cuadro, al que Morán ha consagrado una parte importante de su vida, se fue, día tras dia, a todos los lugares donde en Madrid se dicen versos ${ }^{25}$. Entraba en las salas del Ateneo y observaba la espaciosa galeria de retratos que alli contemplan el paso de los tiempos, como si quisiera constituirse en el continuador de tanta gloria, en el notario del Parnaso que va a dejar constancia de que José Maria Pemán no perdió nunca su aire burlón de jovencito gaditano o de que Federico Muelas era capaz de estar callado, a pesar de las tentaciones que le ofreciera Medrano, en tanto que Conrado pilotaba el retórico barco de su discurso de capitán de "Alforjas".

Mientras daba forma a su proyecto buscaba a los poetas para dibujar sus perfiles y lograr ver su lado feliz y el menos afortunado. Un dia, después de haber dibujado su cara, se le fue para siempre Lope Mateo, y ya, en el futuro, los que quieran saber cómo era el poeta que ganó el certamen del Milenario de Castilla tendrán que ponerse en las manos de José Luis Morán, que supo adelantarse a la Implacable.

\footnotetext{
24 Marino Gomez Santos, En el treinta aniversario de "Alforjas para la poesia". YA. Madrid, 20-I-1974.

PS Luis López ANGLADA “Frente a frente con José Luis Morán». Estafeta Literaria, n 502. Madrid, 15-X-1972. págs. 33-35.
} 
Cuando ya tenia decidida la composición del cuadro y habia oido miles de poemas y se le habia transfigurado el espíritu a fuerza de tanta literatura, José Luis Morán fue pintando su obra, seguramente con el mismo cuidado miniaturista con que Esquivel fue dejando en el lienzo los rostros de los románticos que acudian a oír a Zorrilla en su estudio.

Para terminar, no me resisto a la tentación de mostrar la incidencia de esta línea literario-política en las creaciones actuales. Ortuño nos brinda una caricatura de una serie de figuras plenamente conocidas cuya vida puede contemplarse bajo estas dos vertientes. Se trata de Enrique Tierno Galván, Manuel Fraga Iribarne, Carlos Barral, Rafael Alberti, Fernando Morán López, Santiago Carrillo Solares, Ramón Tamames y Leopoldo Calvo Sotelo. No nos detenemos en su comentario, pues el testimonio gráfico, pensamos, es suficiente. 


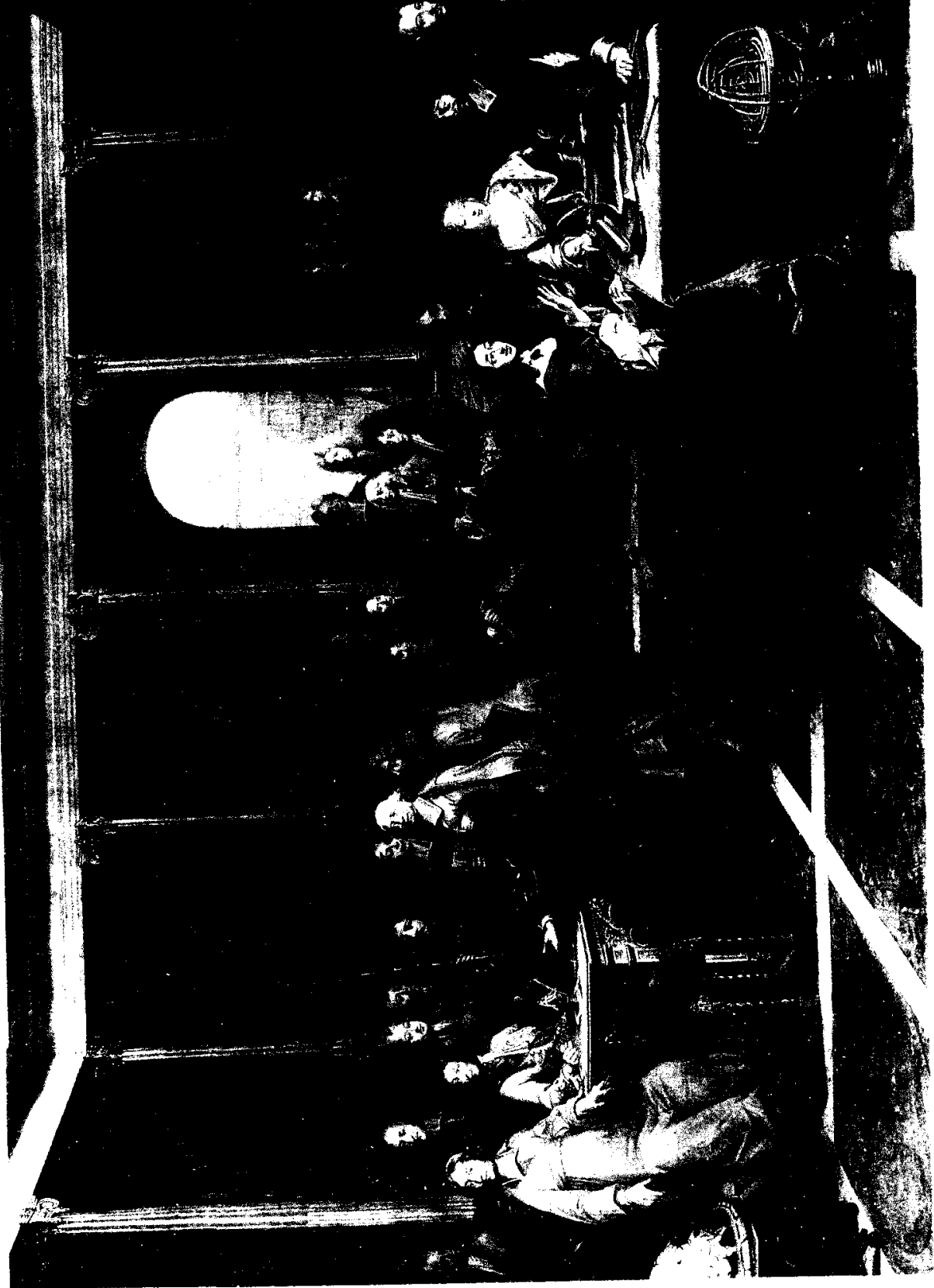

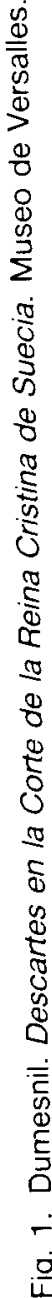




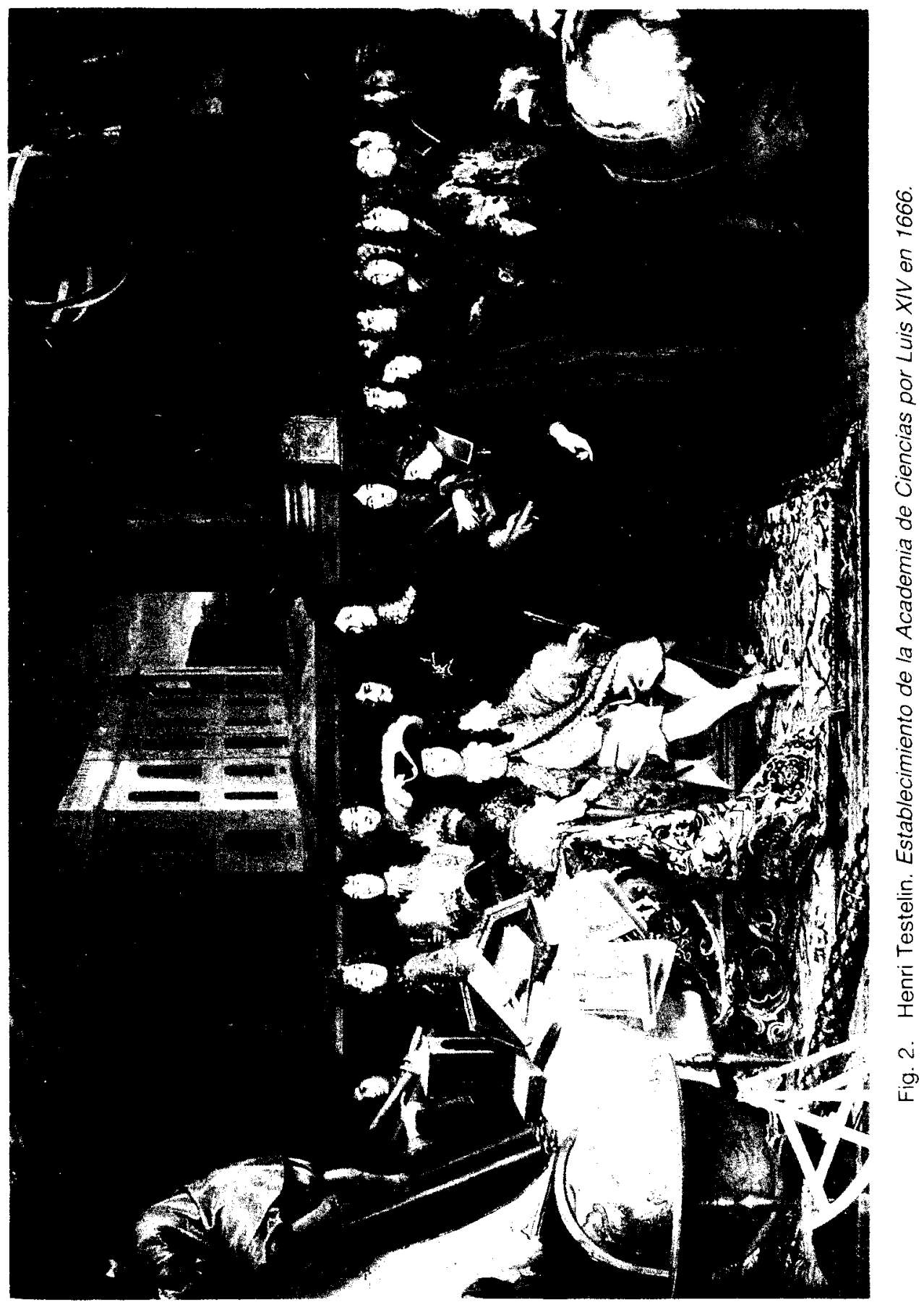




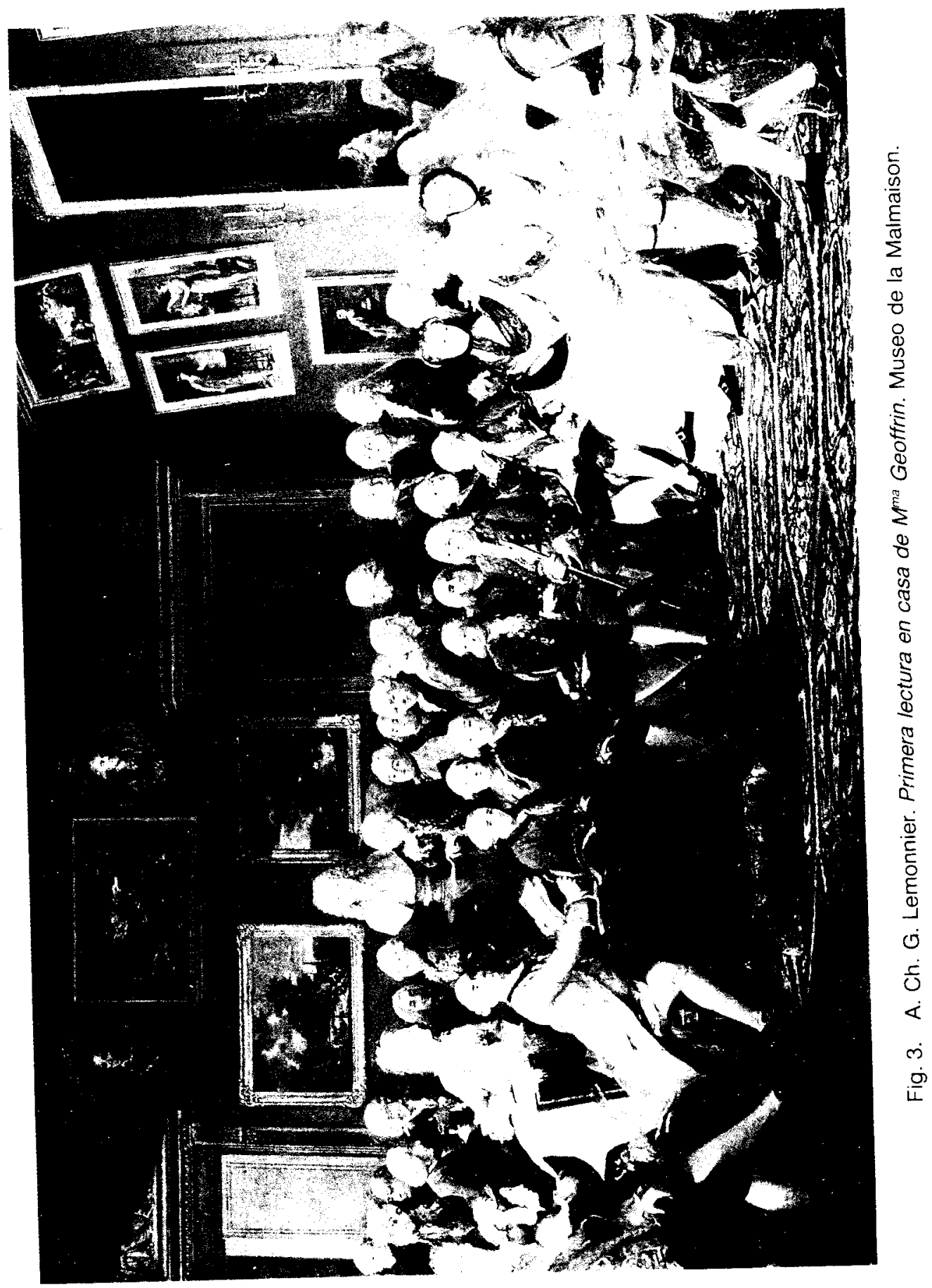




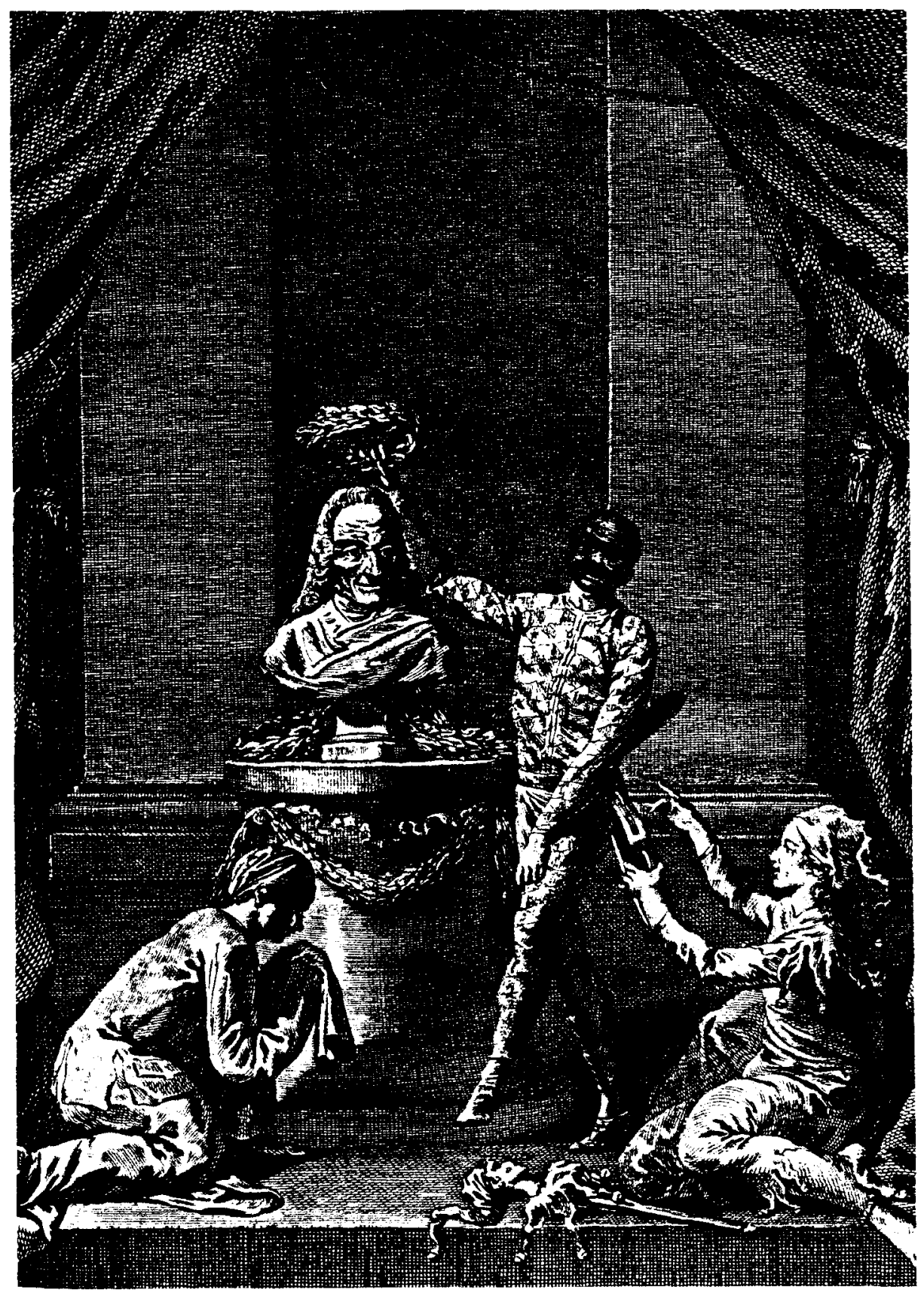

Fig. 4. Voltaire, coronado por los comediantes franceses, el 30 de marzo de 1778. B.N. de París. 


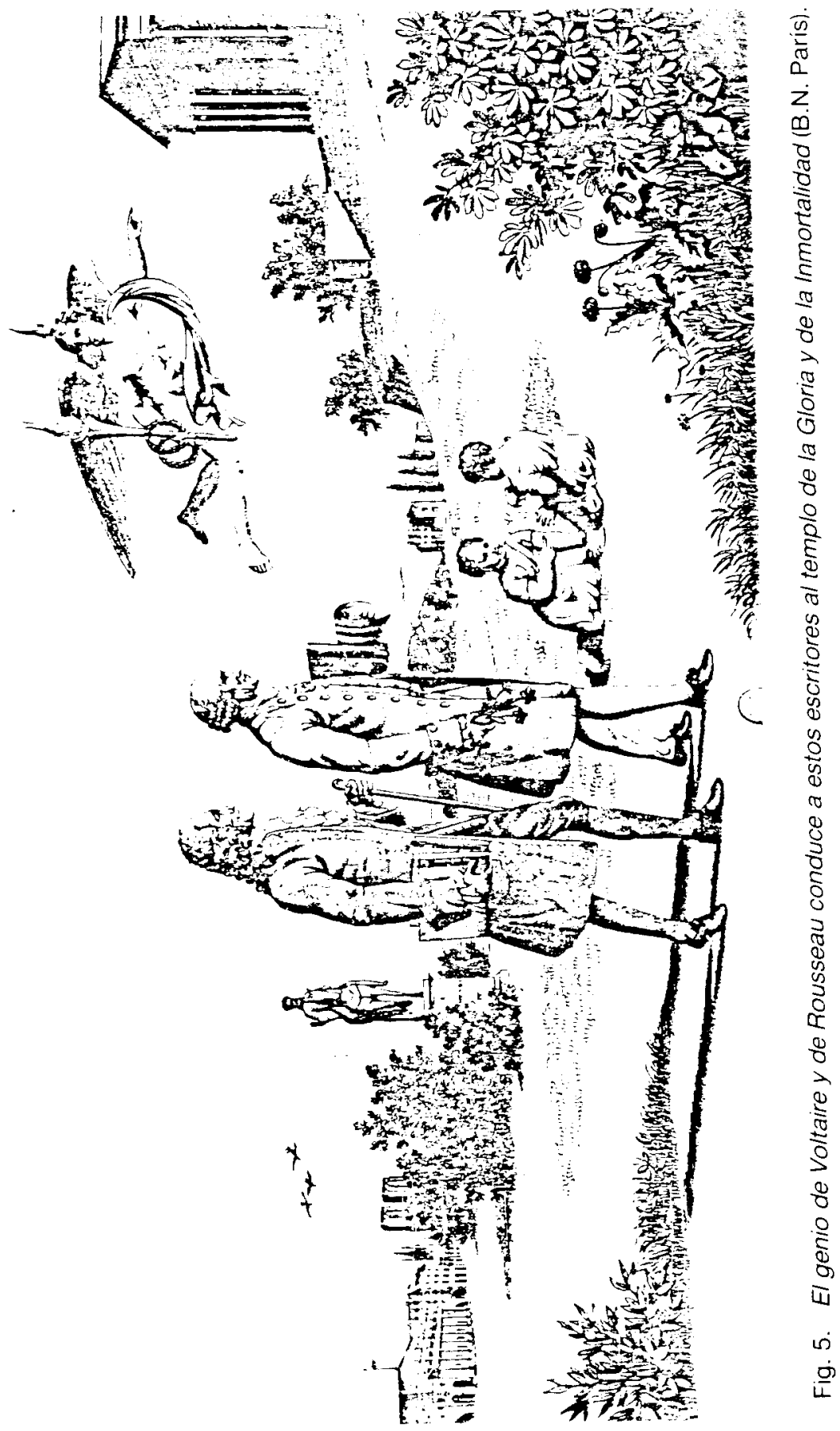




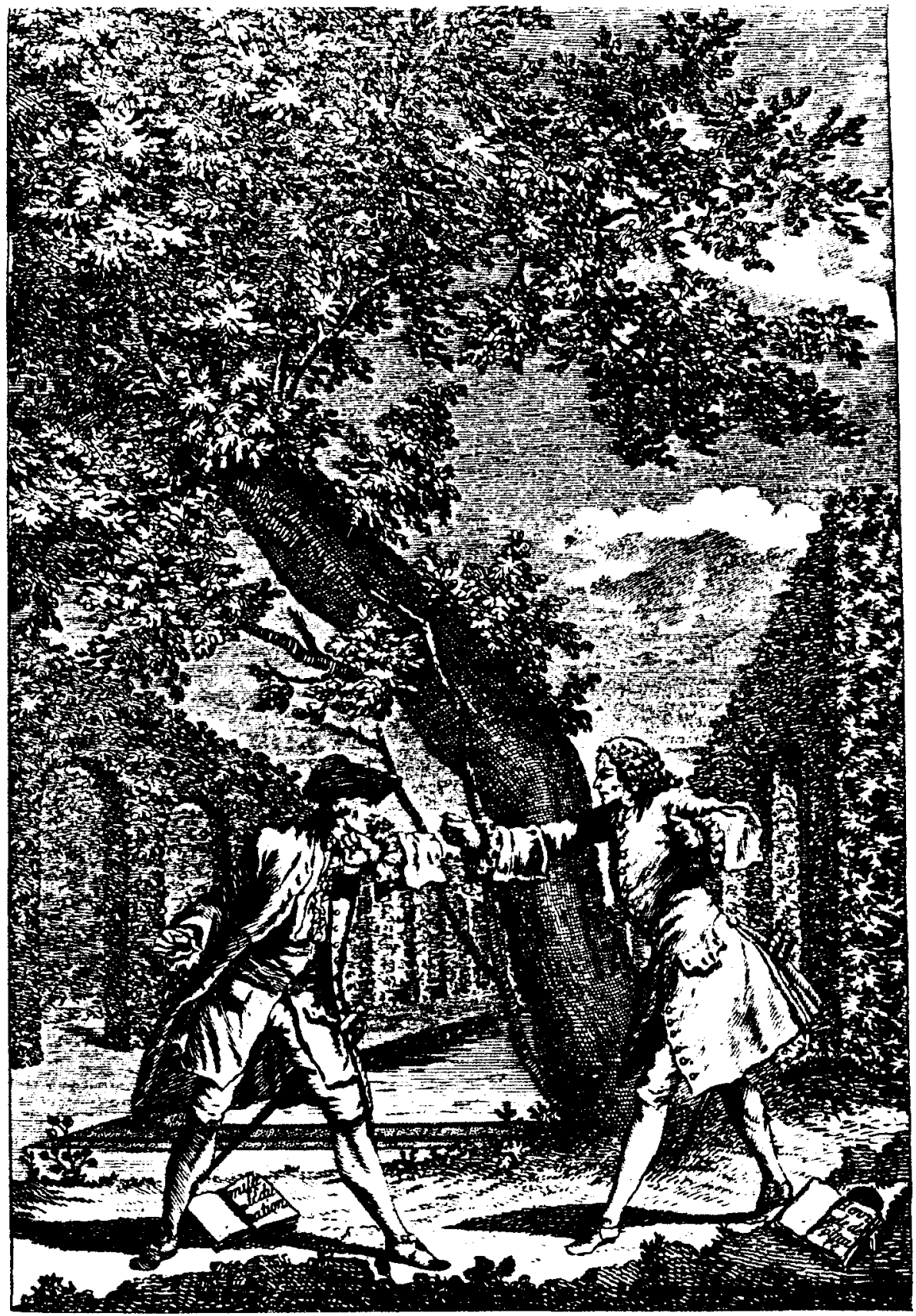

Fig. 6. Rousseau y Voltaire "en lucha». Grabado anónımo. B.N. de París. 


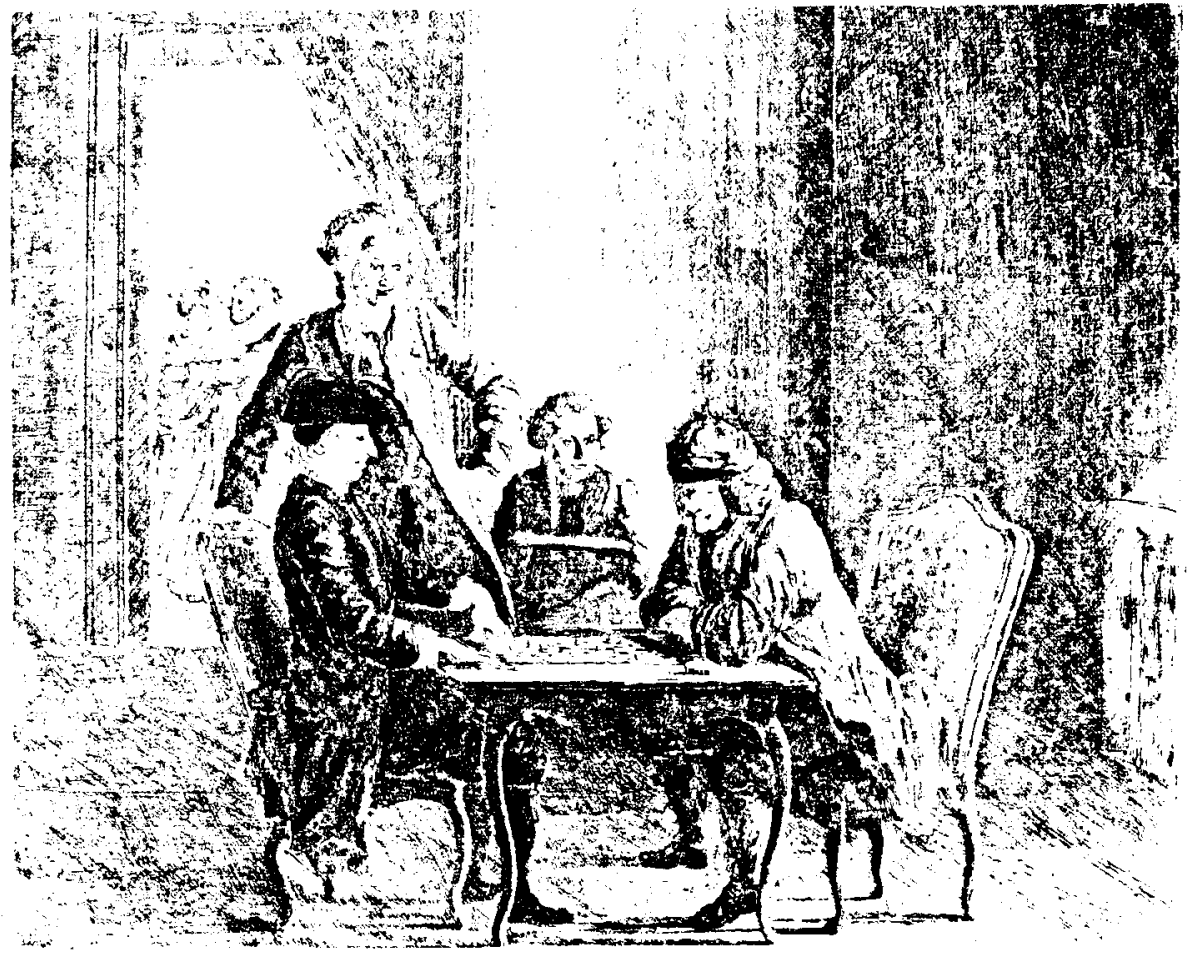

Fig. 7. Voltaire jugando a las damas con el Padre Adam. Grabado de Huber. B.N. de París. Fot. Giraudon.

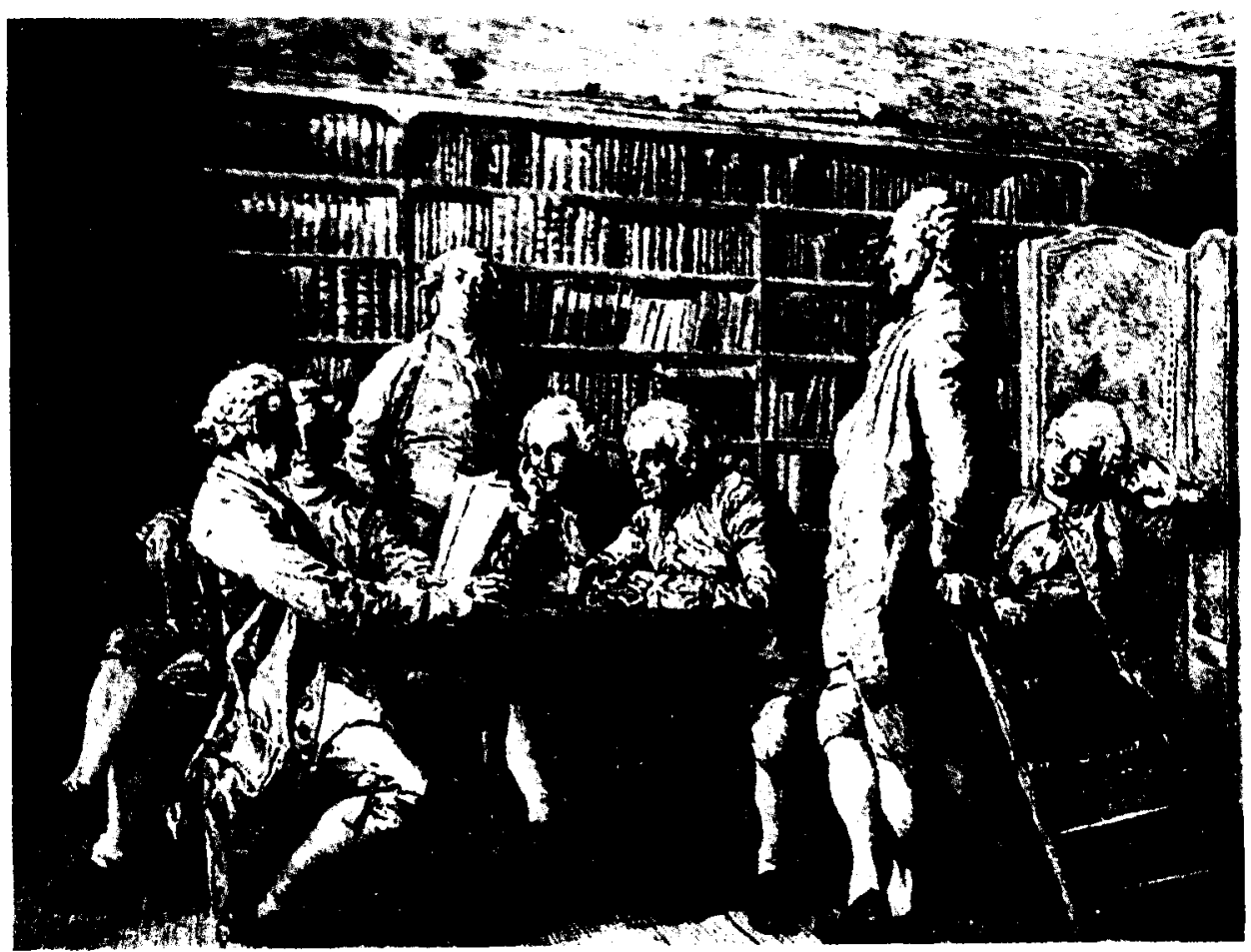

Fig. 8. Lectura en casa de Diderot. Grabado de Mongin según una pintura de Meissonier. 


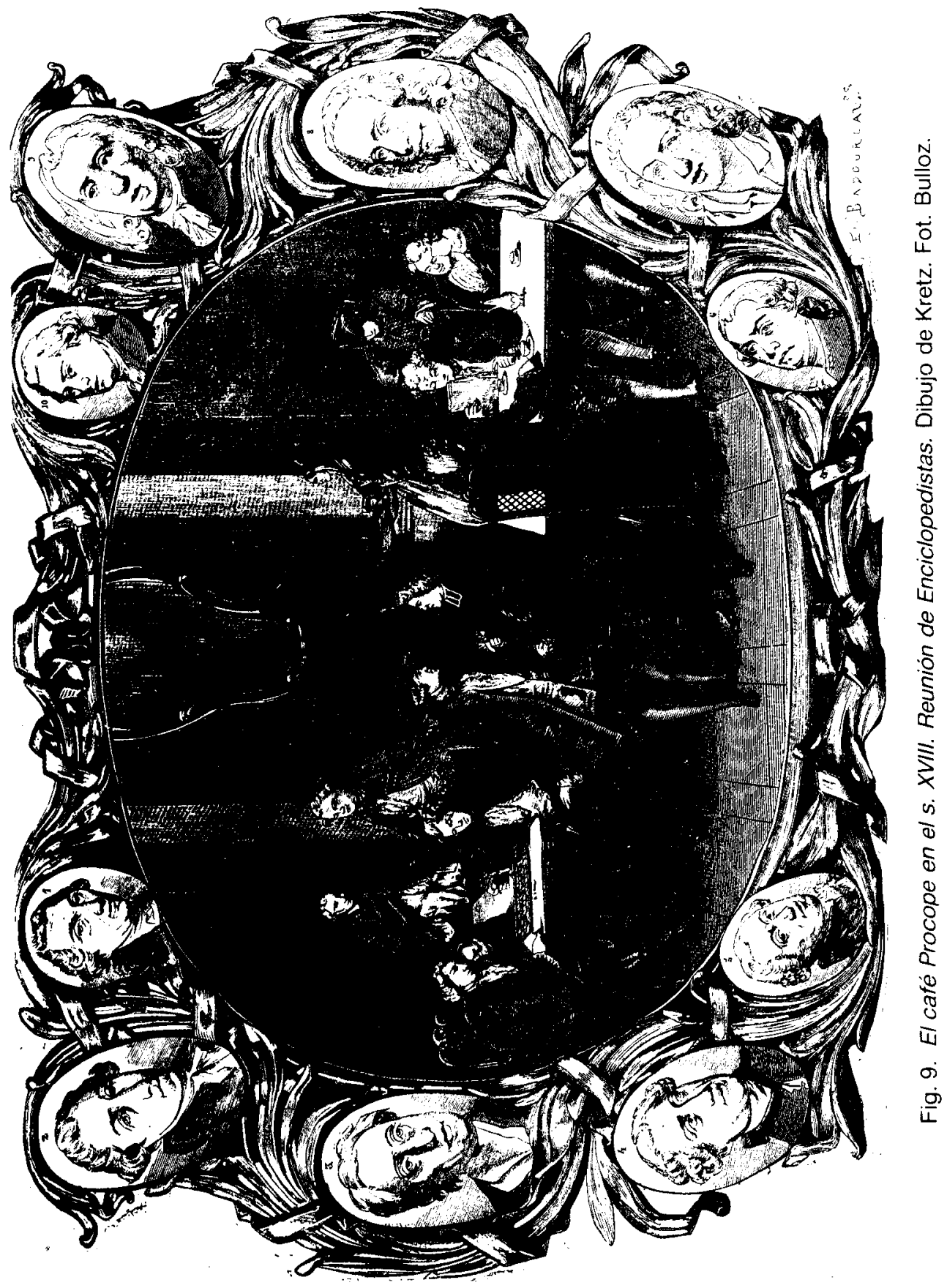




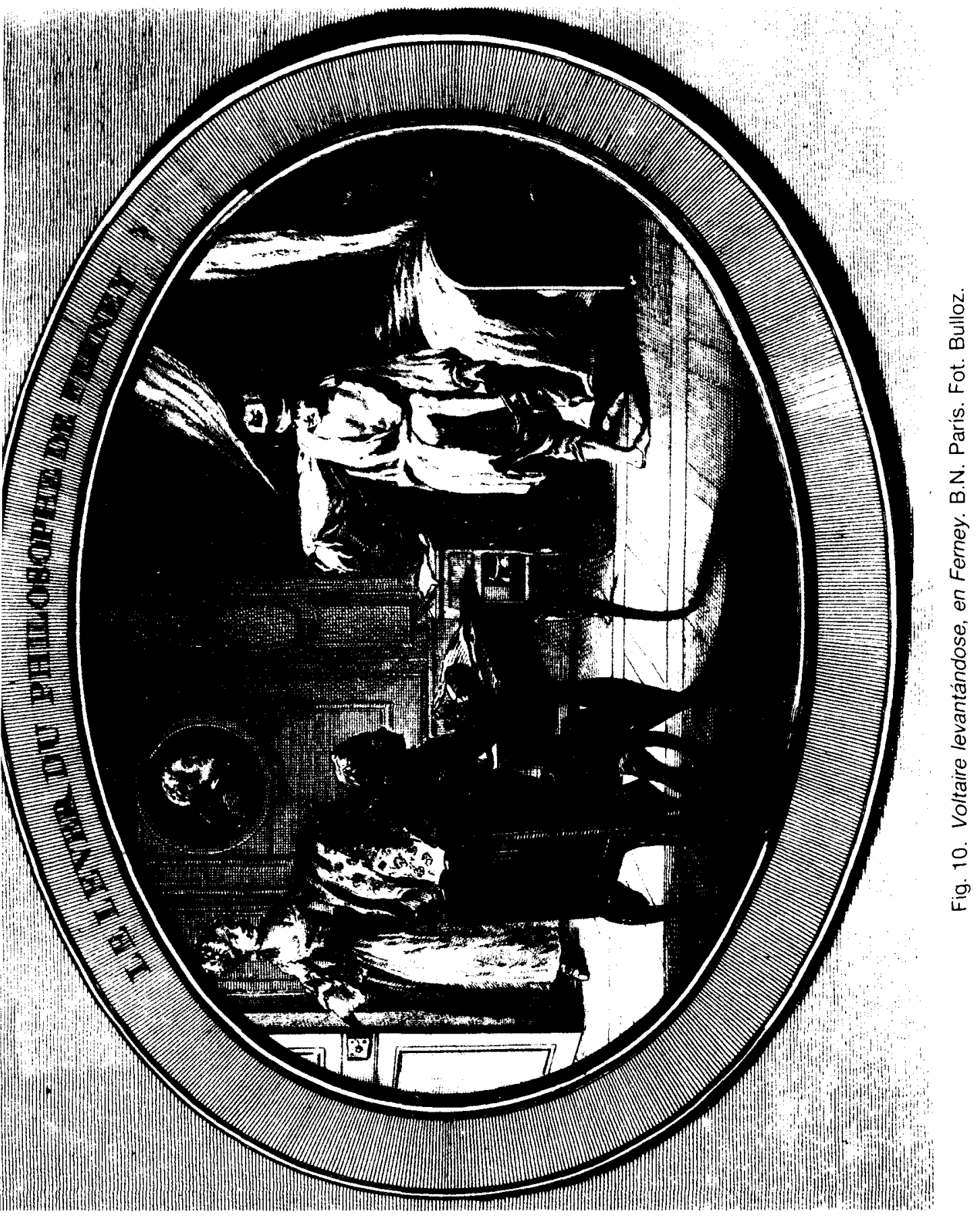




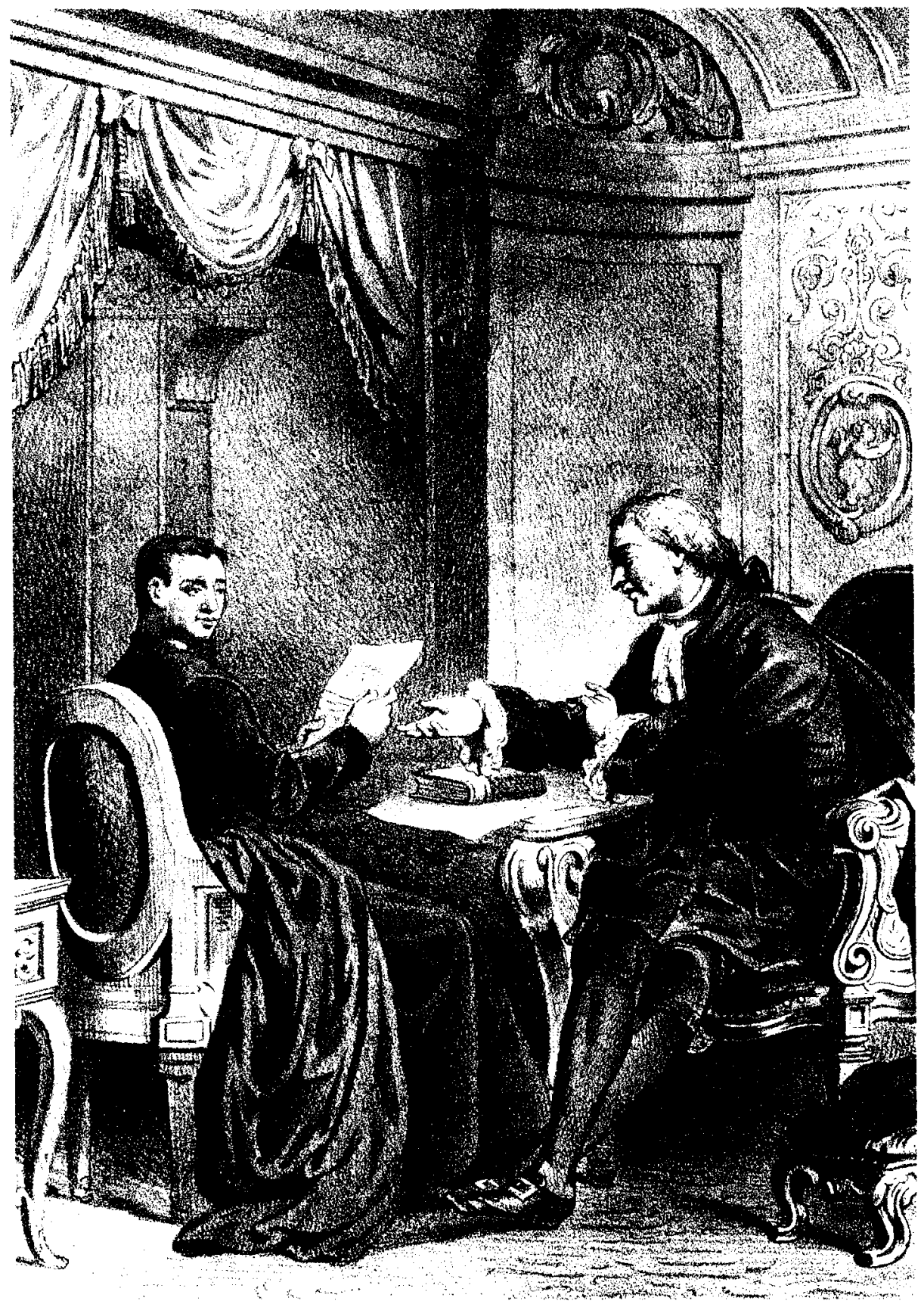

Fig. 11. El P. Andrés Burriel y el doctor Pérez Bayer. 


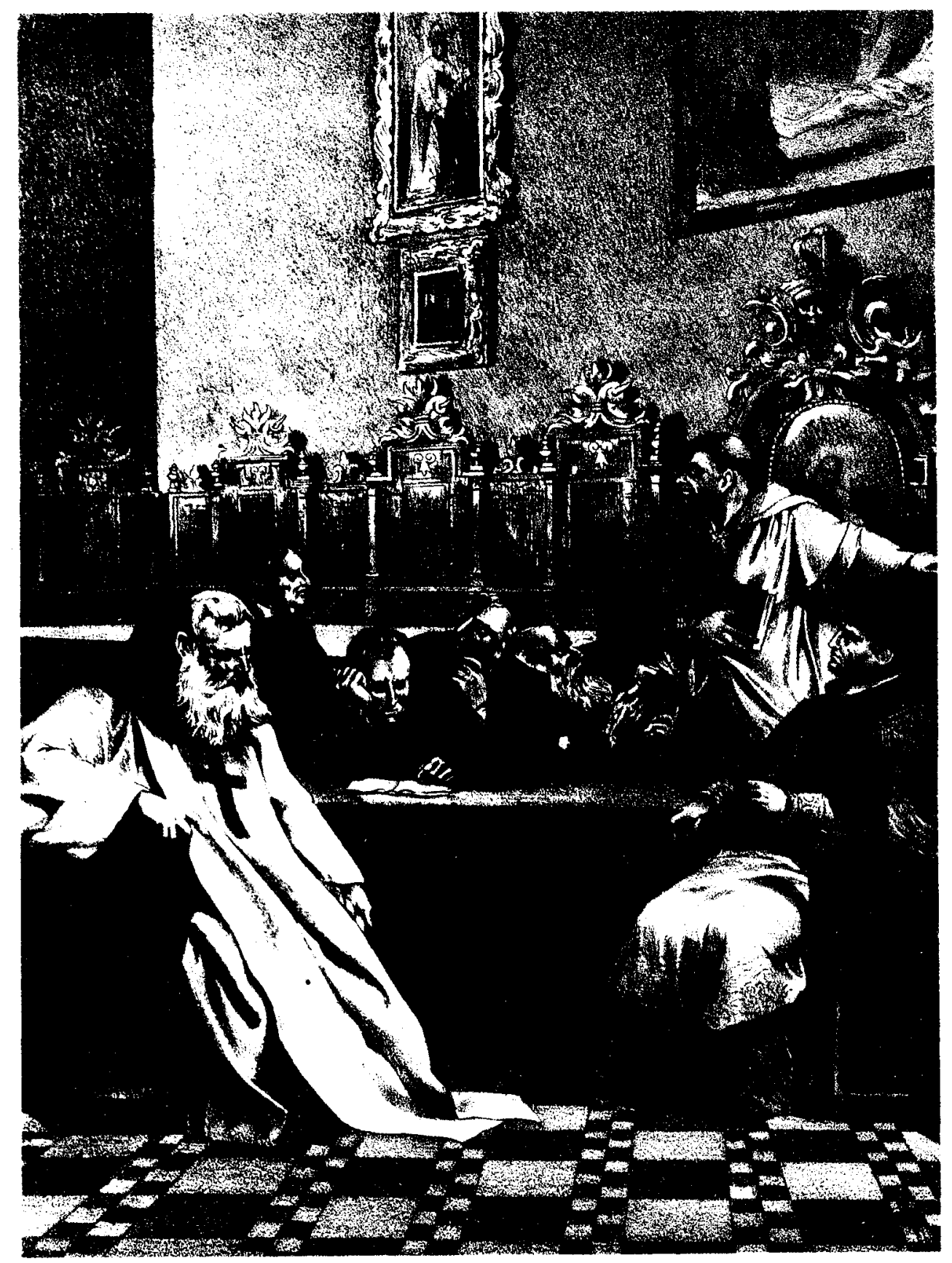

Fig. 12. Portocarrero preside una junta de Teólogos. Lit. Serra-Vidal. 


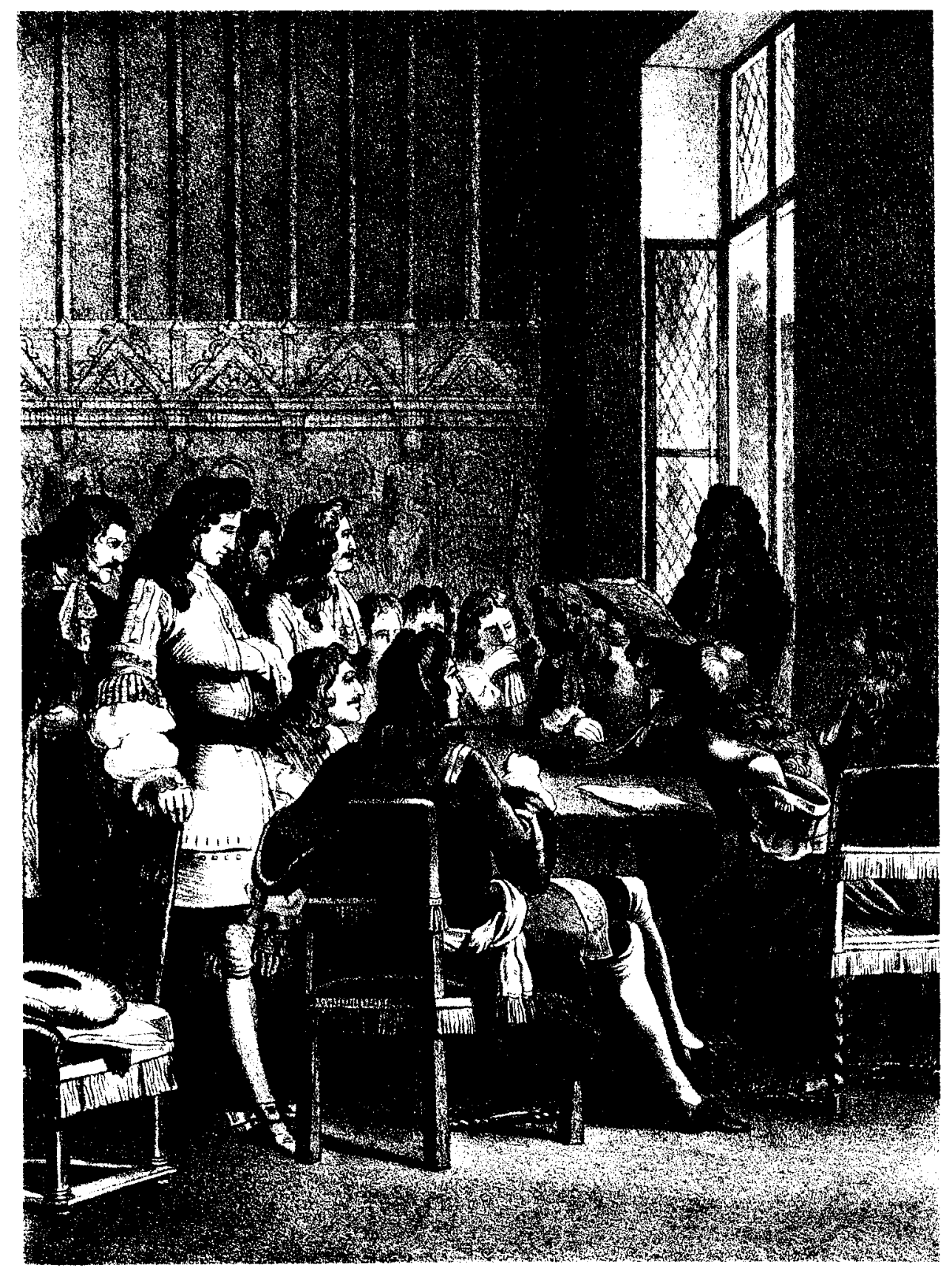

Fig. 13. Monteleón ante los Estados Generales en La Haya. Lit. Serra-Vidal. 


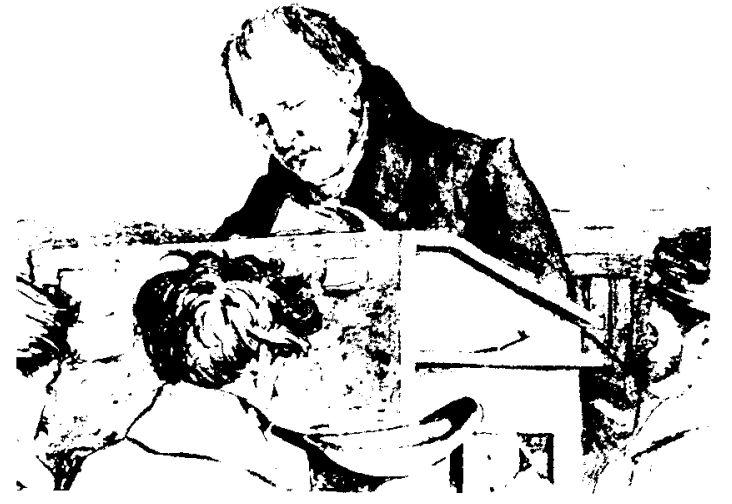

(1)

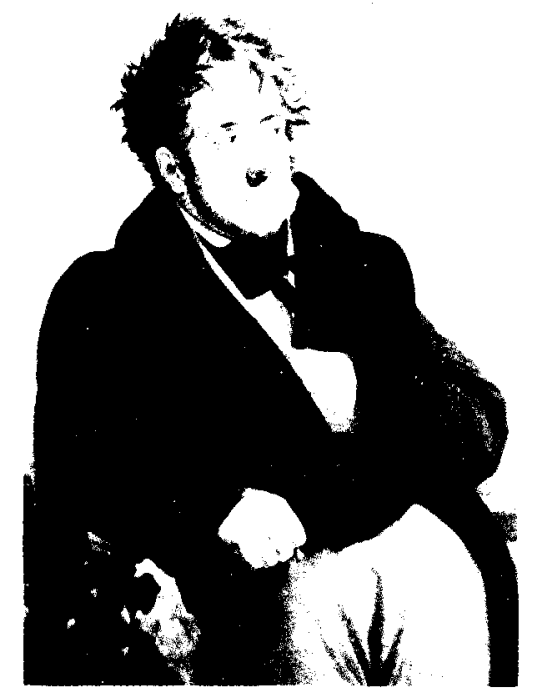

(4)
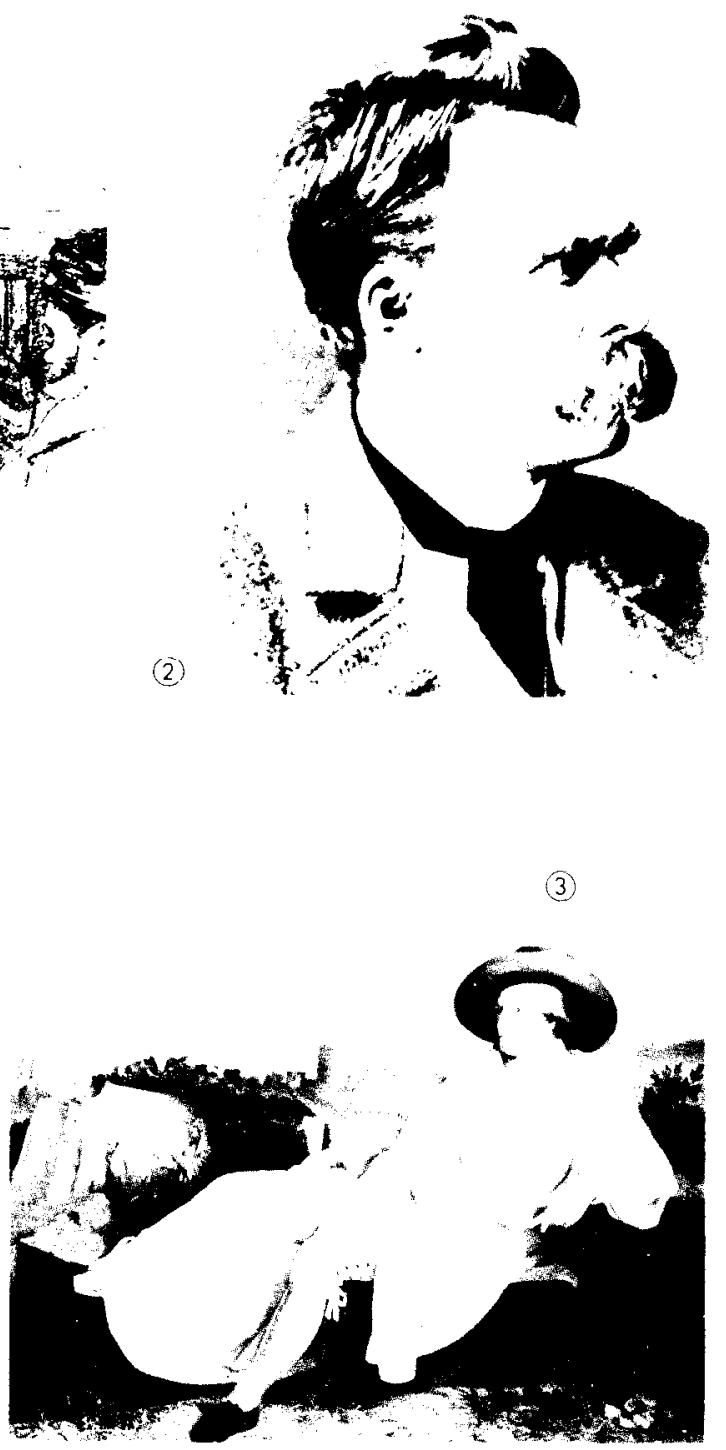

Fig. 14. 14, G.F. Wilhelm Hegel (Dibujo de 1828); 14, F. Nietzsche (fotografia); 14, Goethe (por Tischbein); $14_{4}$ Chateaubriand (por Girodet) 


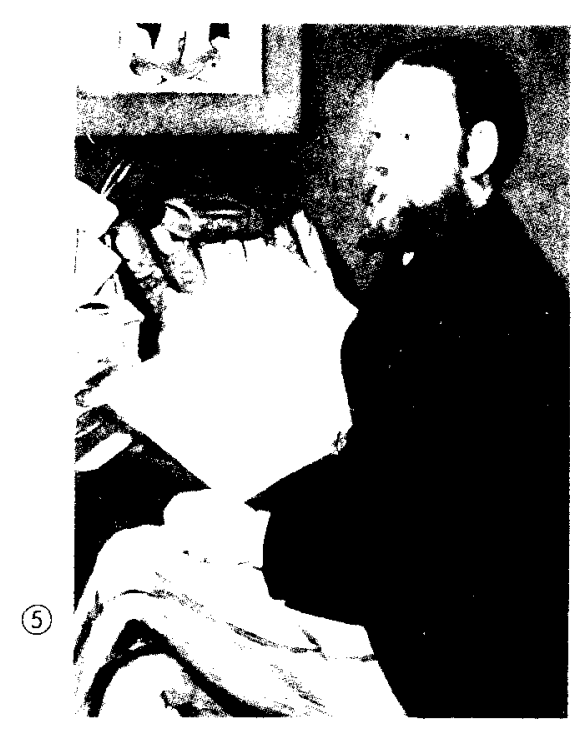

(6)

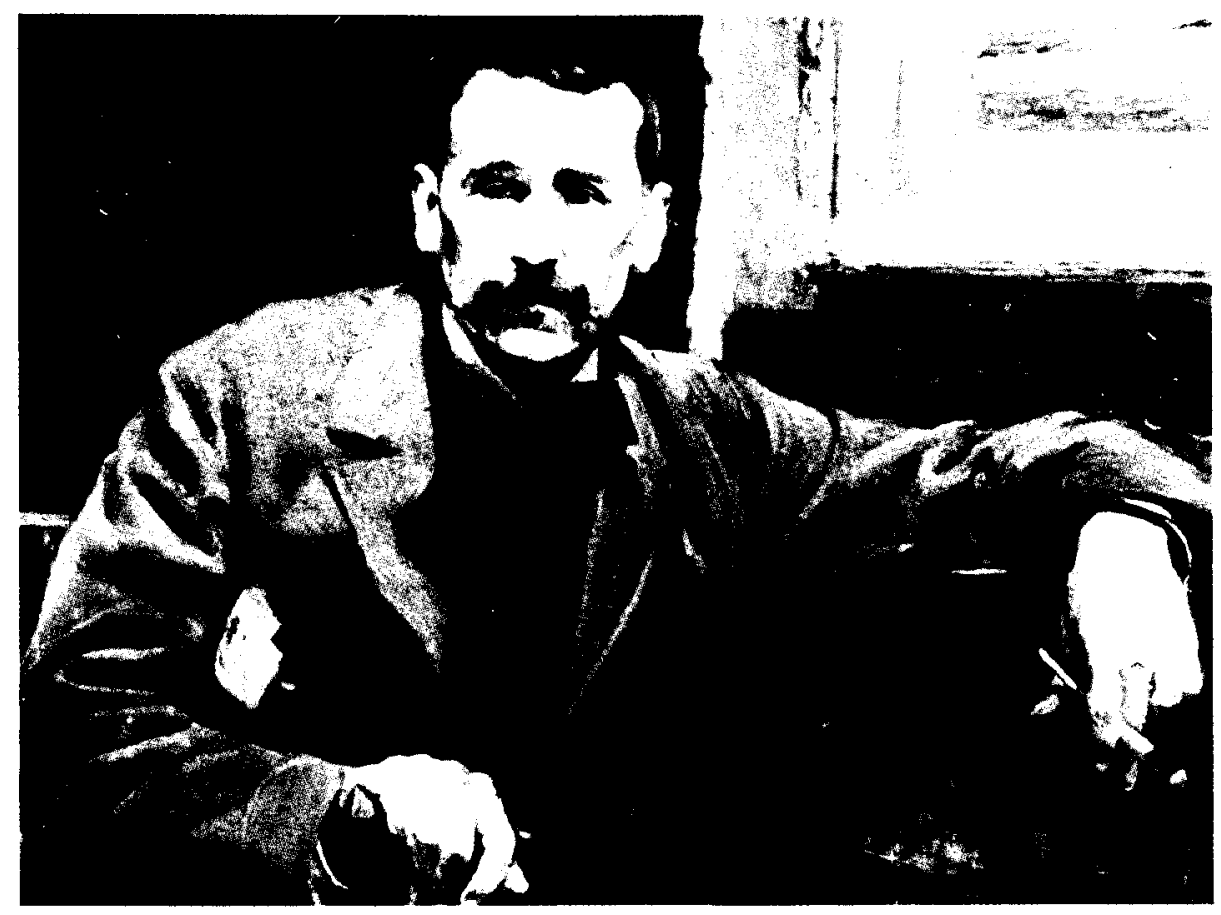

Fig. 14. 14, Emilio Zola (por Manel); 14 Pérez Galdos (por Sorolla). 


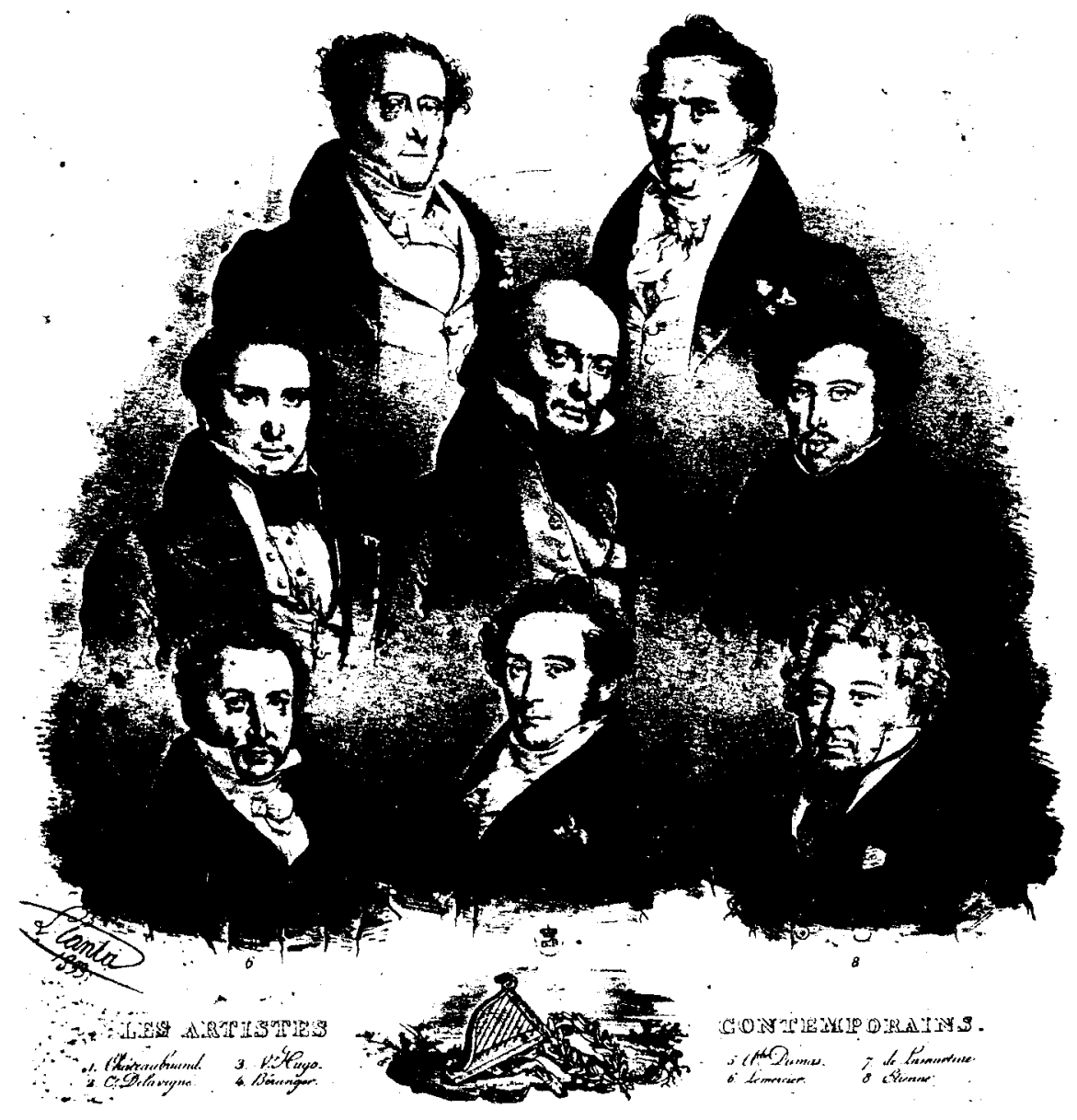

Fig. 15. Los artistas contemporáneos. Grabado de Llanta. 1833. B.N. de París. 


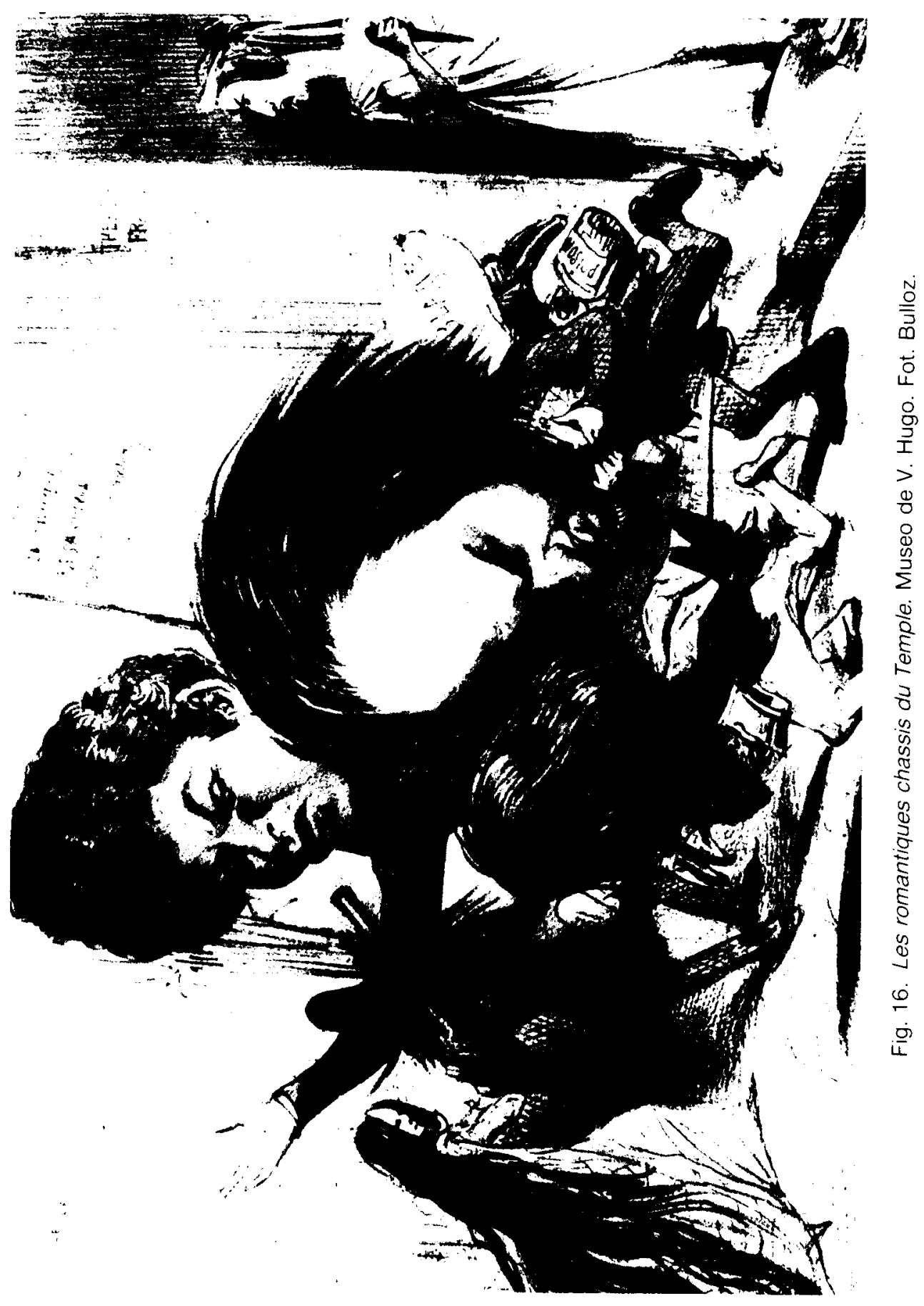




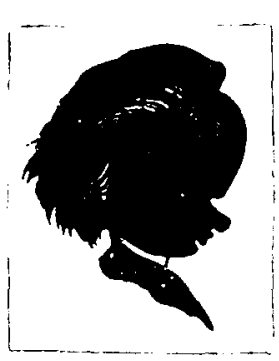

III (3).

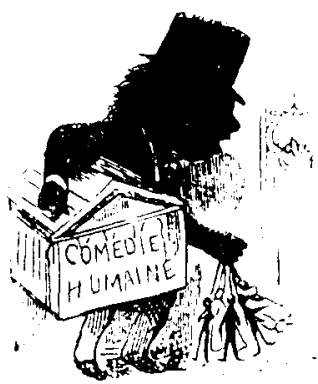

DE B.AIZ.1C:

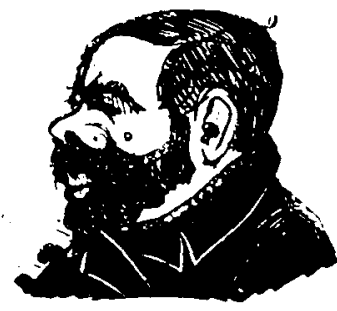

J. CKÉTIXENE-JOLY.

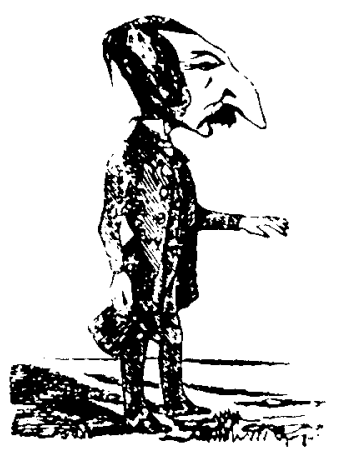

FLIE UERTHET

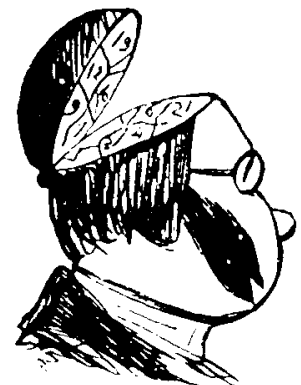

1.F DOCTELR PJiCE.

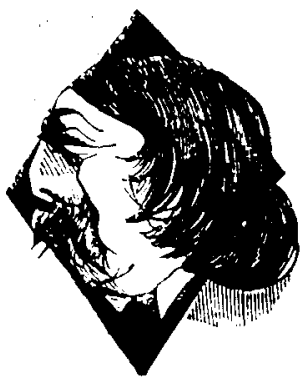

rHÉOPIHLE (i.UTHIEA.

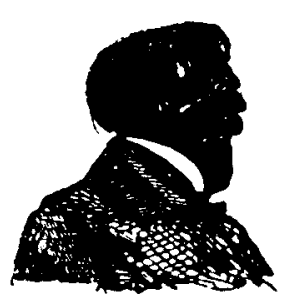

IUGUSTE IIREU.

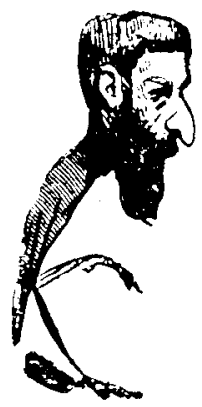

ECGENE PELLETAN

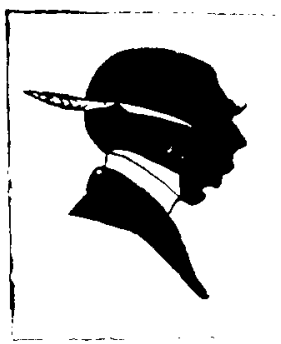

SCIIIUE.

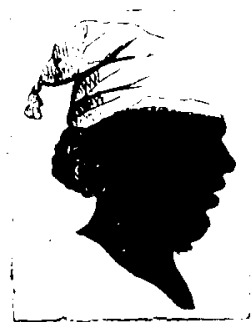

AULES IANIN.
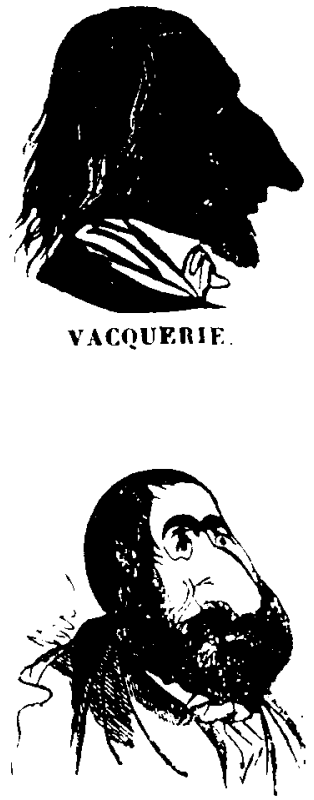

JIBINALd

Fig. 17. "Panteón caricaturesco de escritores célebres". Del Libro de los 400 autores. Museo de Balzac. 


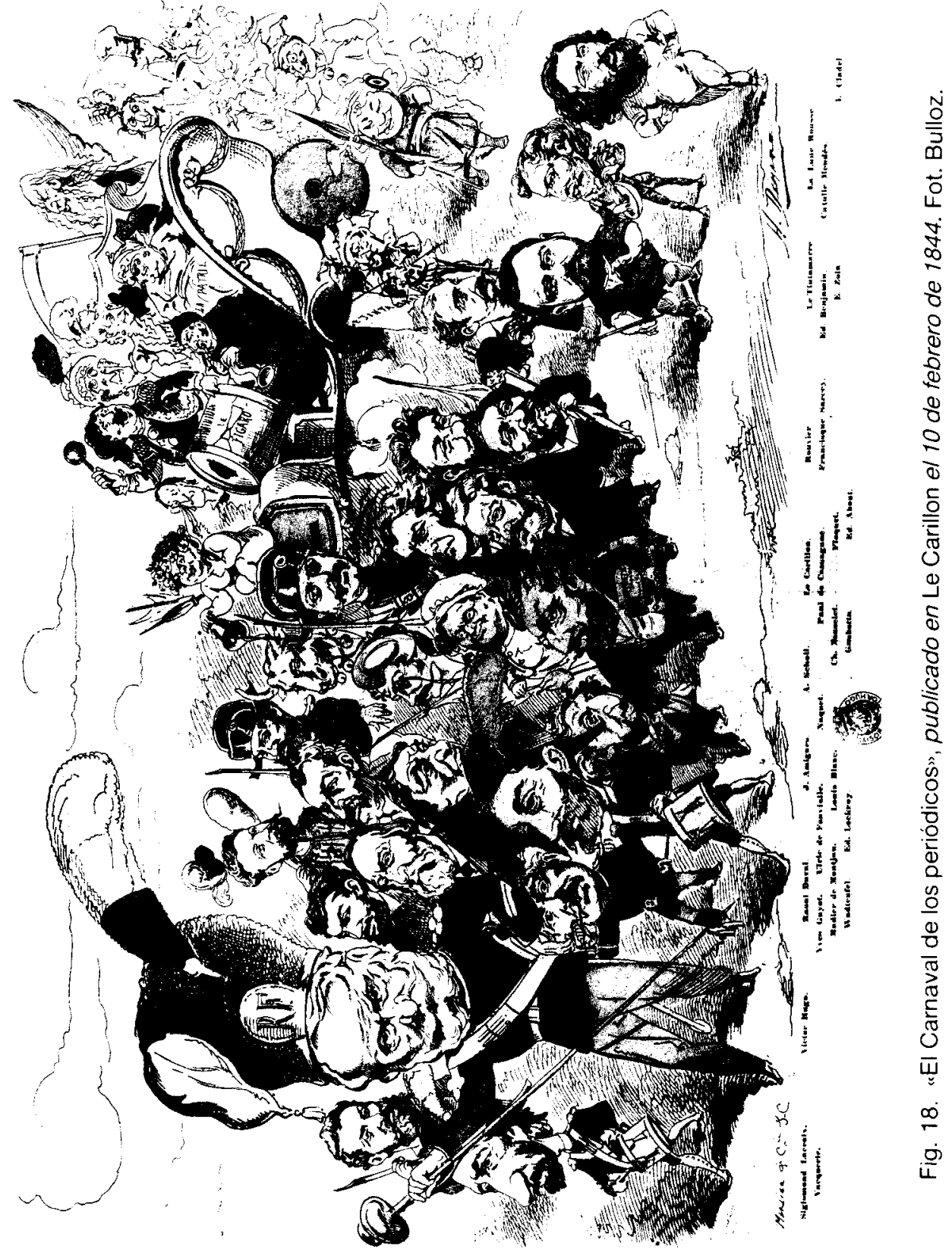




$$
\text { \& }
$$

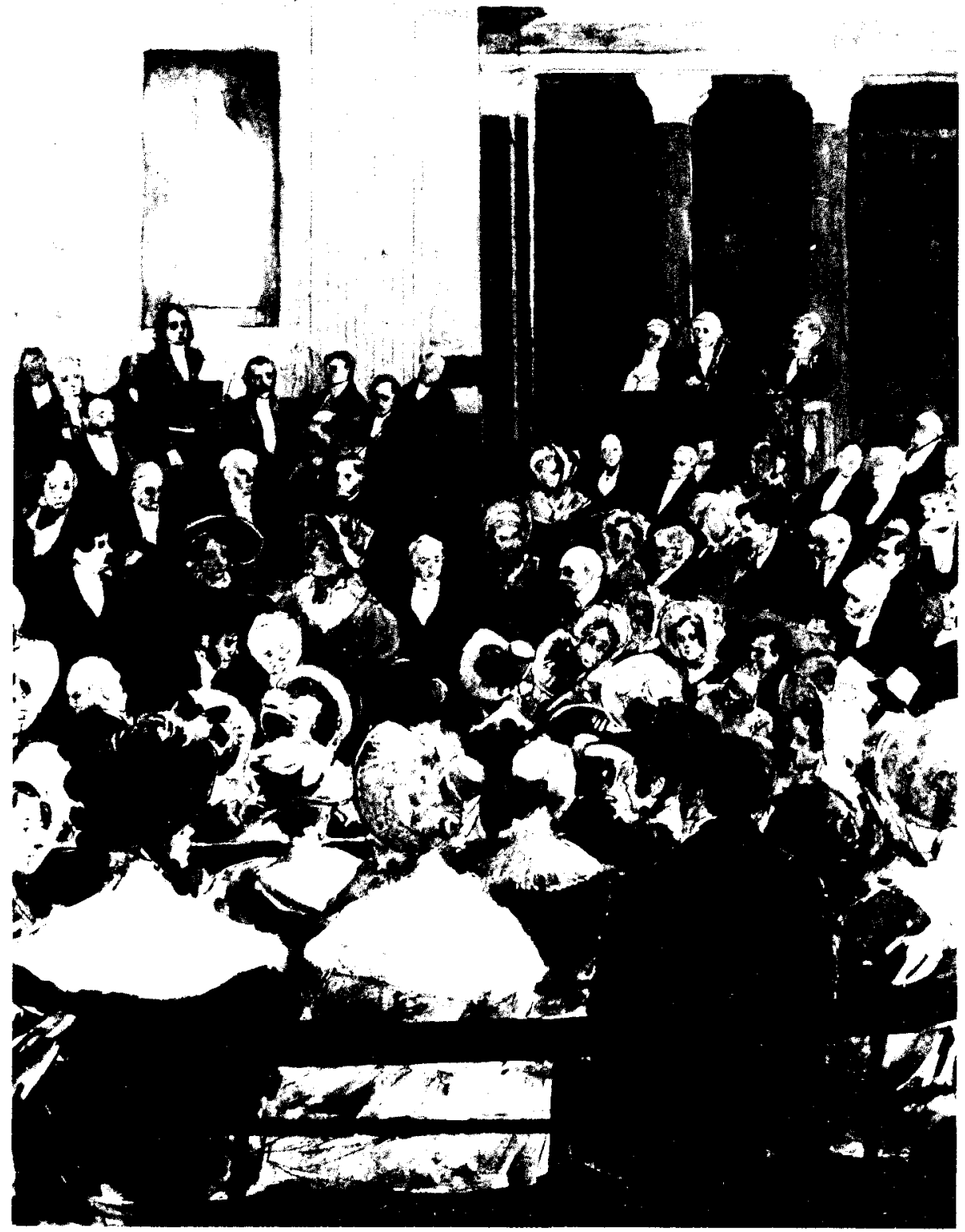

Fig. 19. Recepción de V. Hugo en la Academia Francesa en 1841. Dibujo en color de Vogel. Museo de V. Hugo. Fot. Bulloz. 


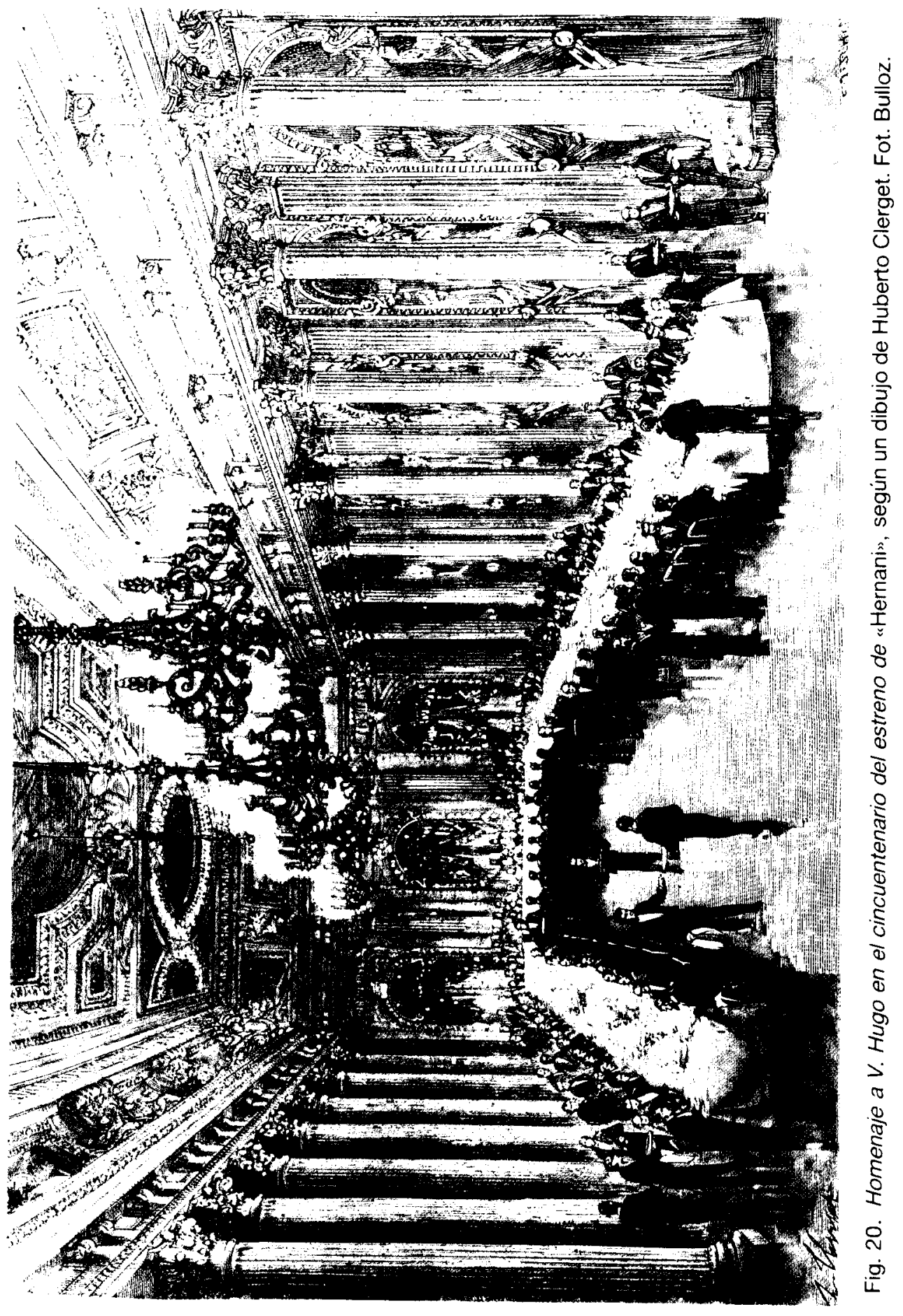




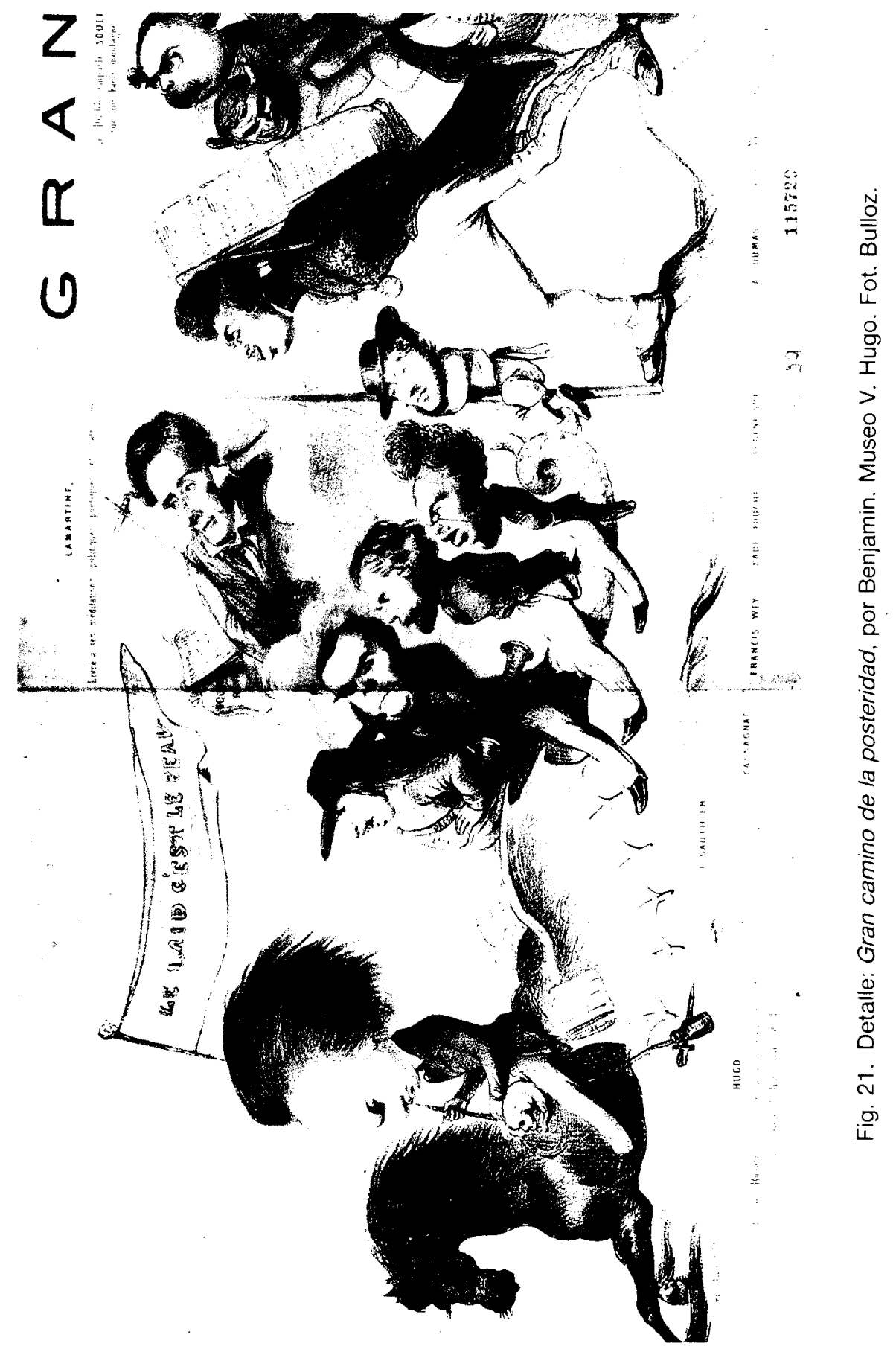




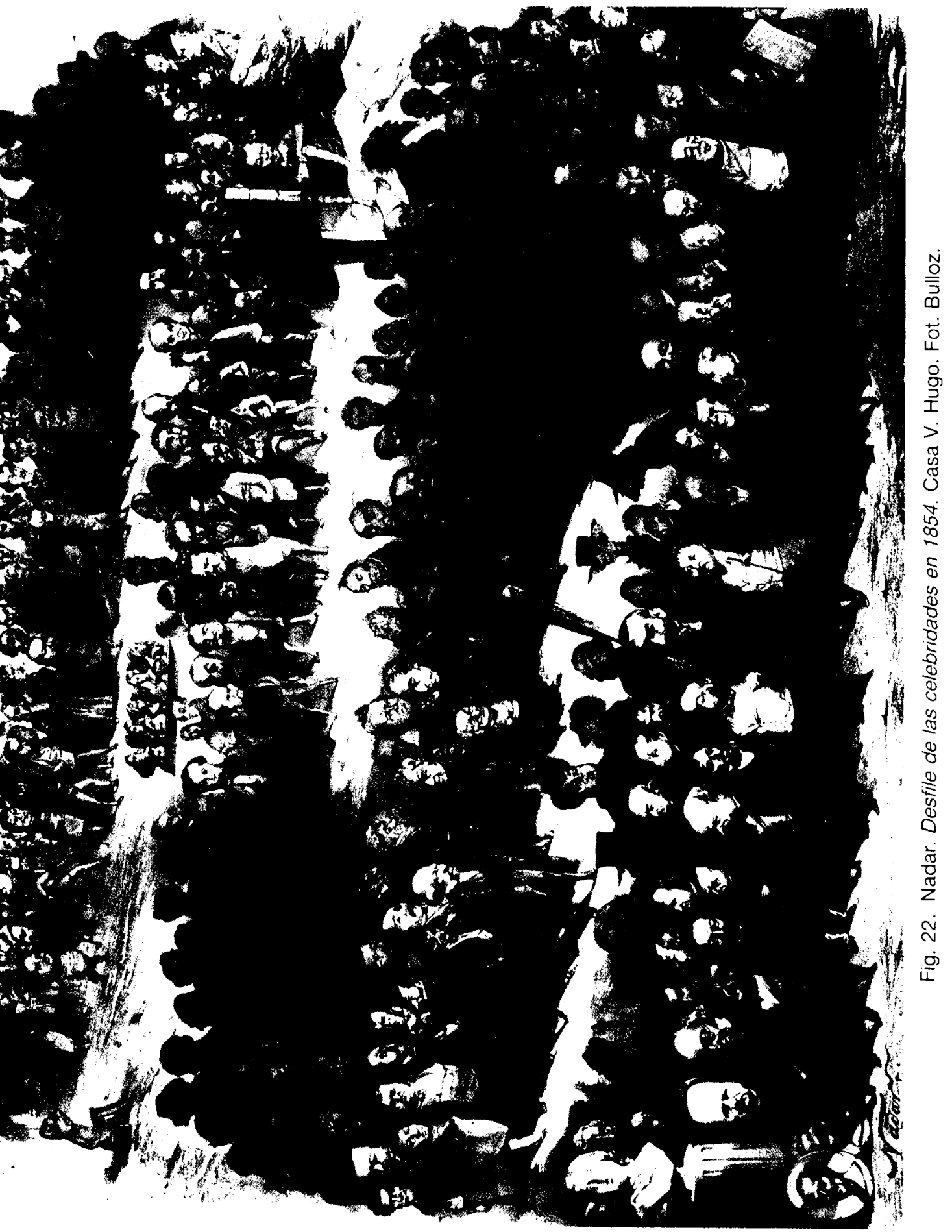



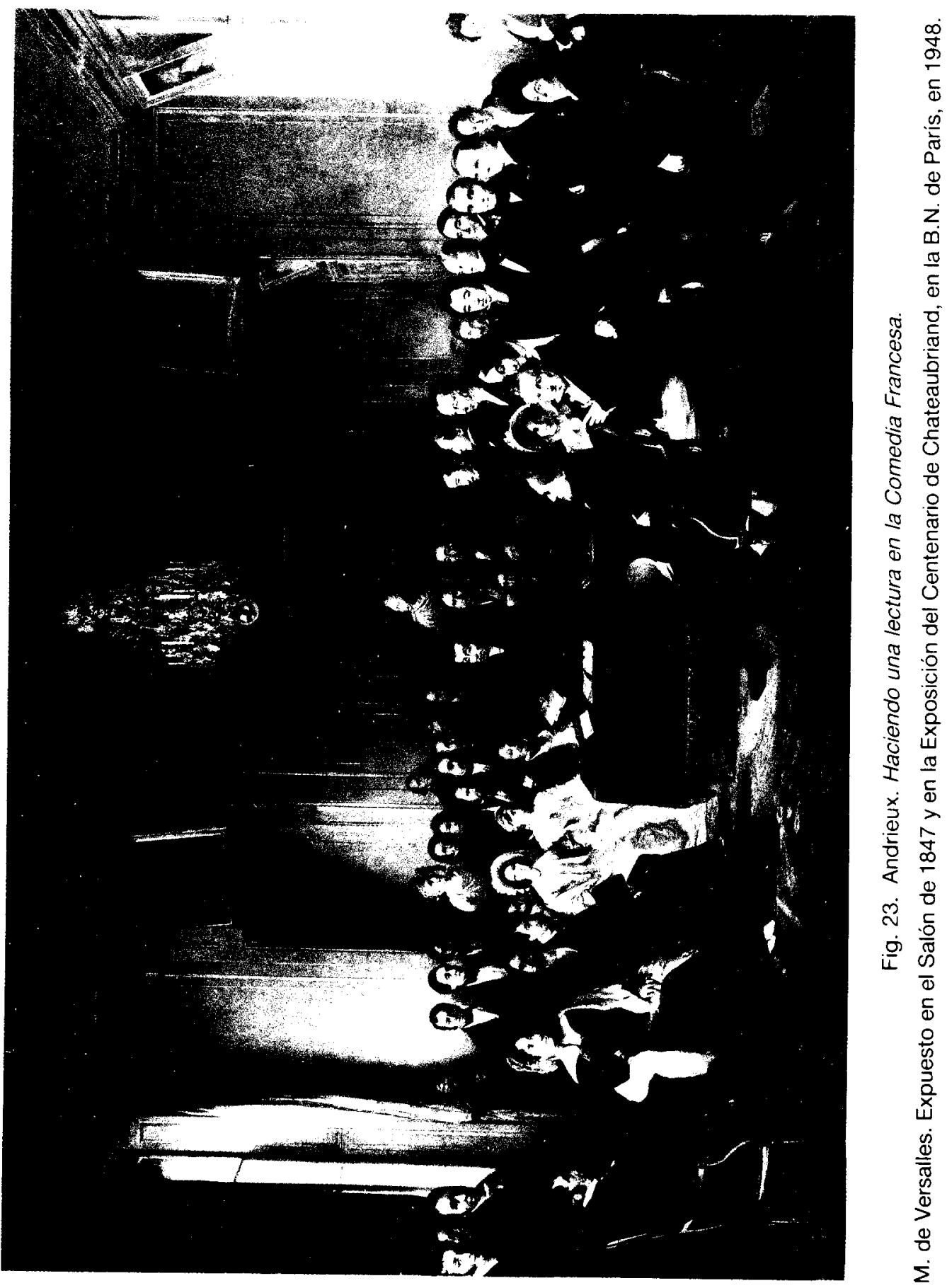


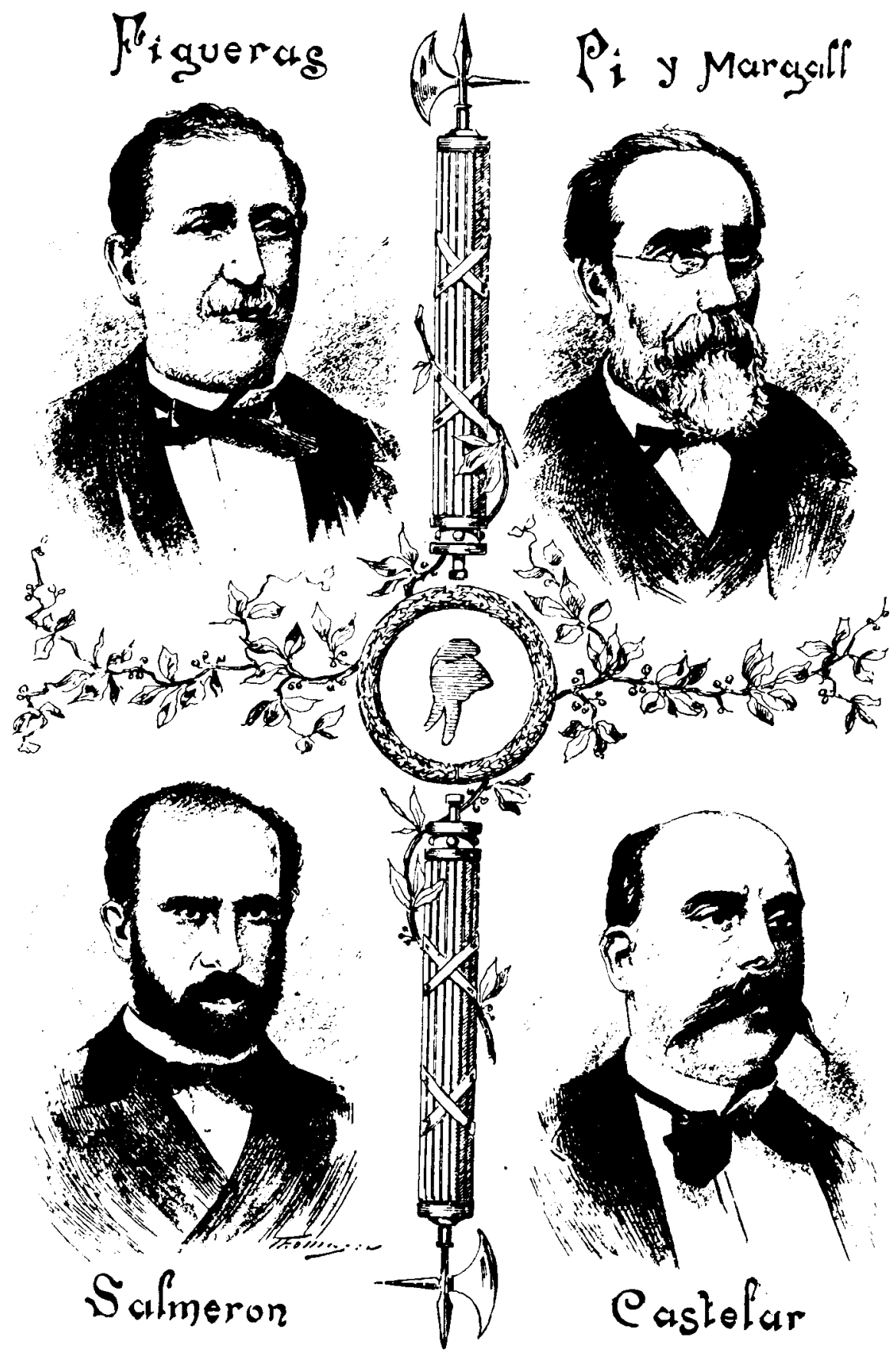

Fig. 24. Los cuatro Presidentes de la / República. 

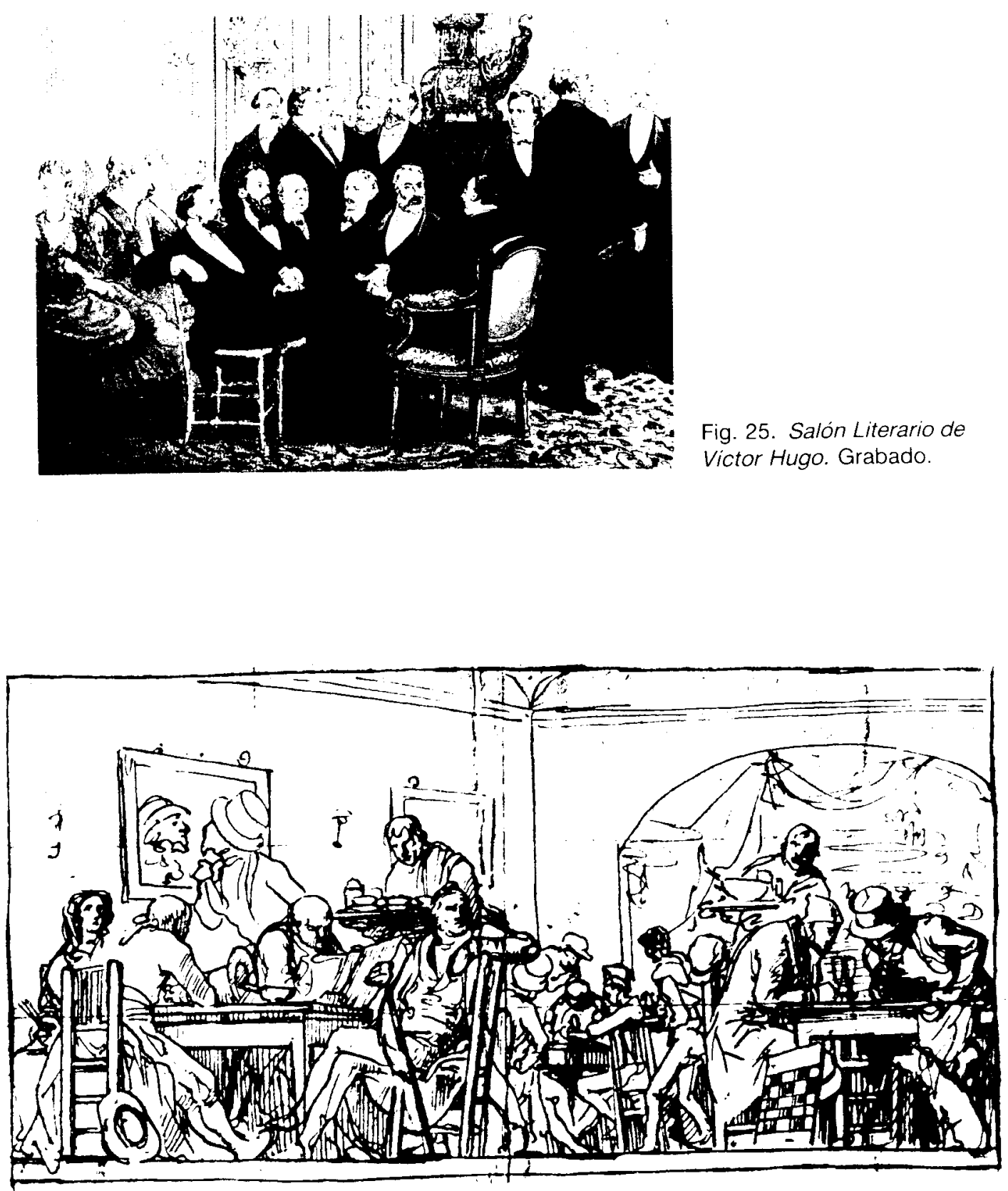

Fig. 26. El café Levante. Dibujo de Alenza. 


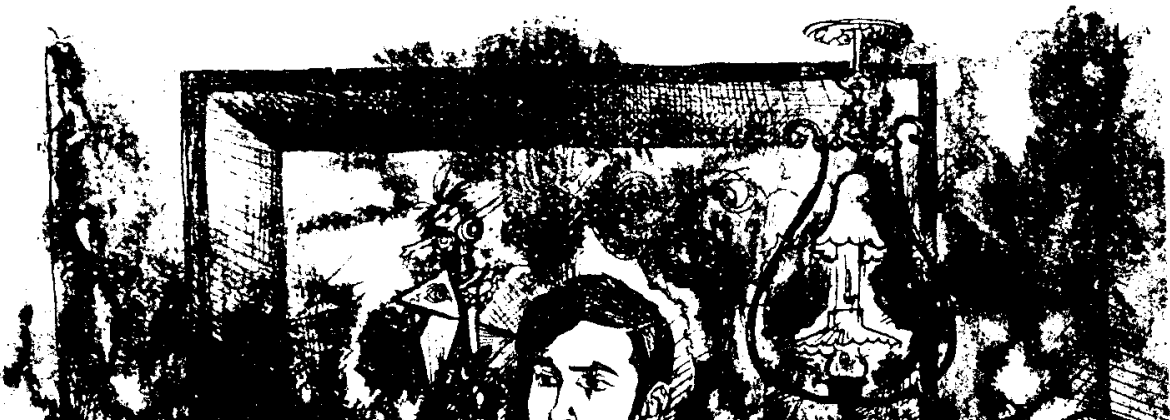
and $(4)^{2}$

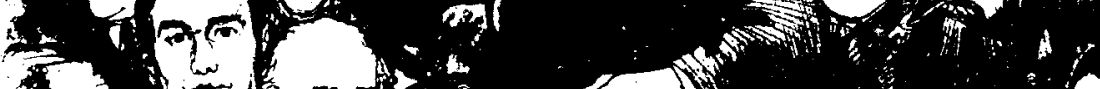
$x_{0}$

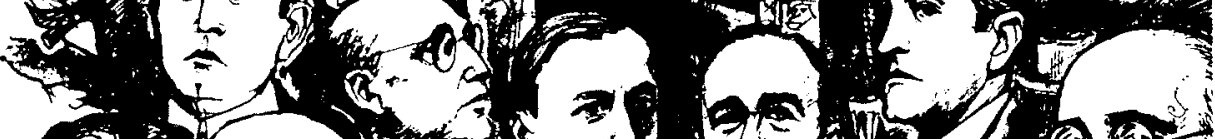

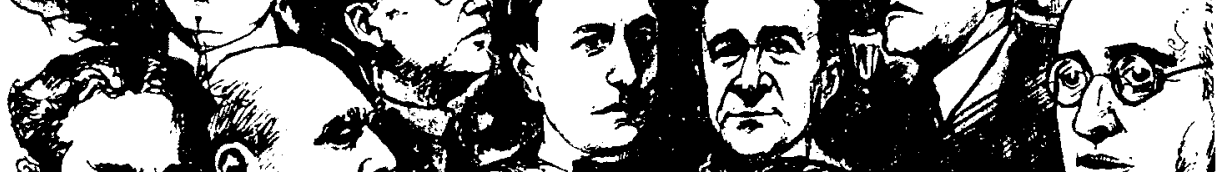

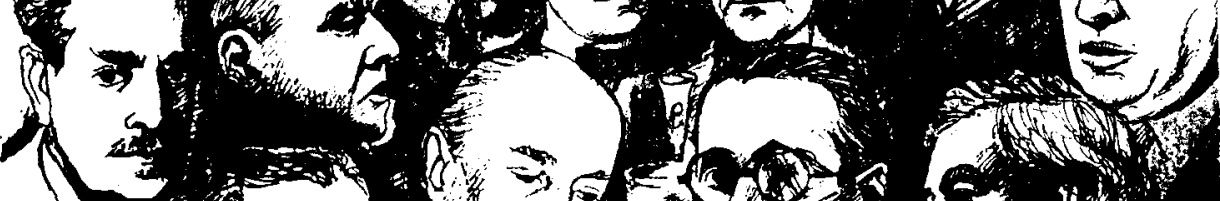

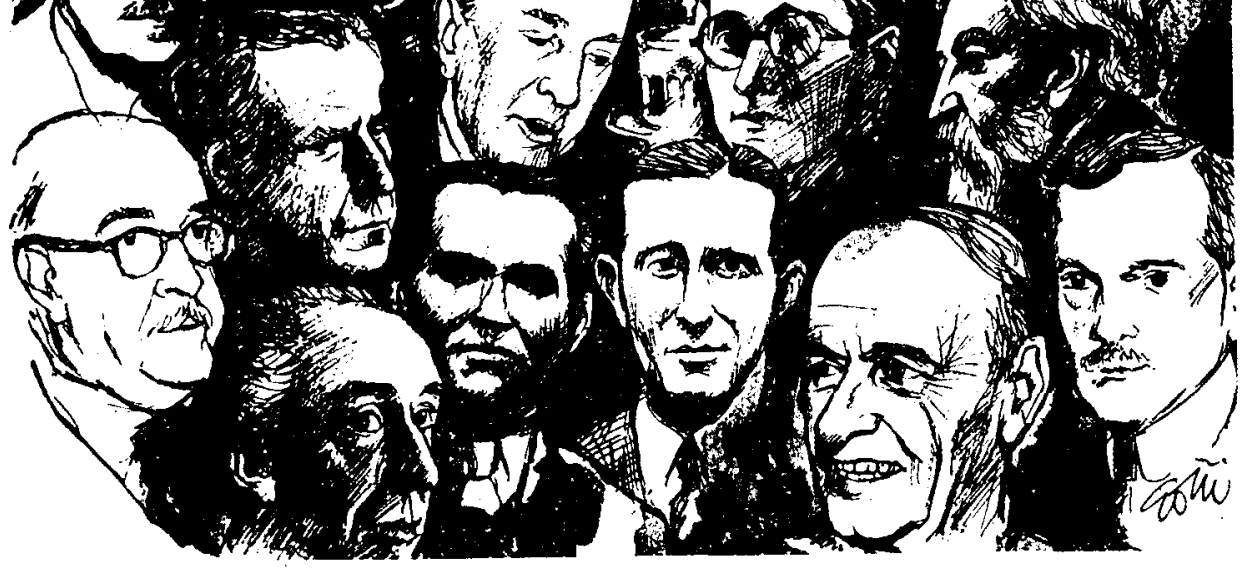
Fig. 27. Goñi: Tertulia de "Pombo". 


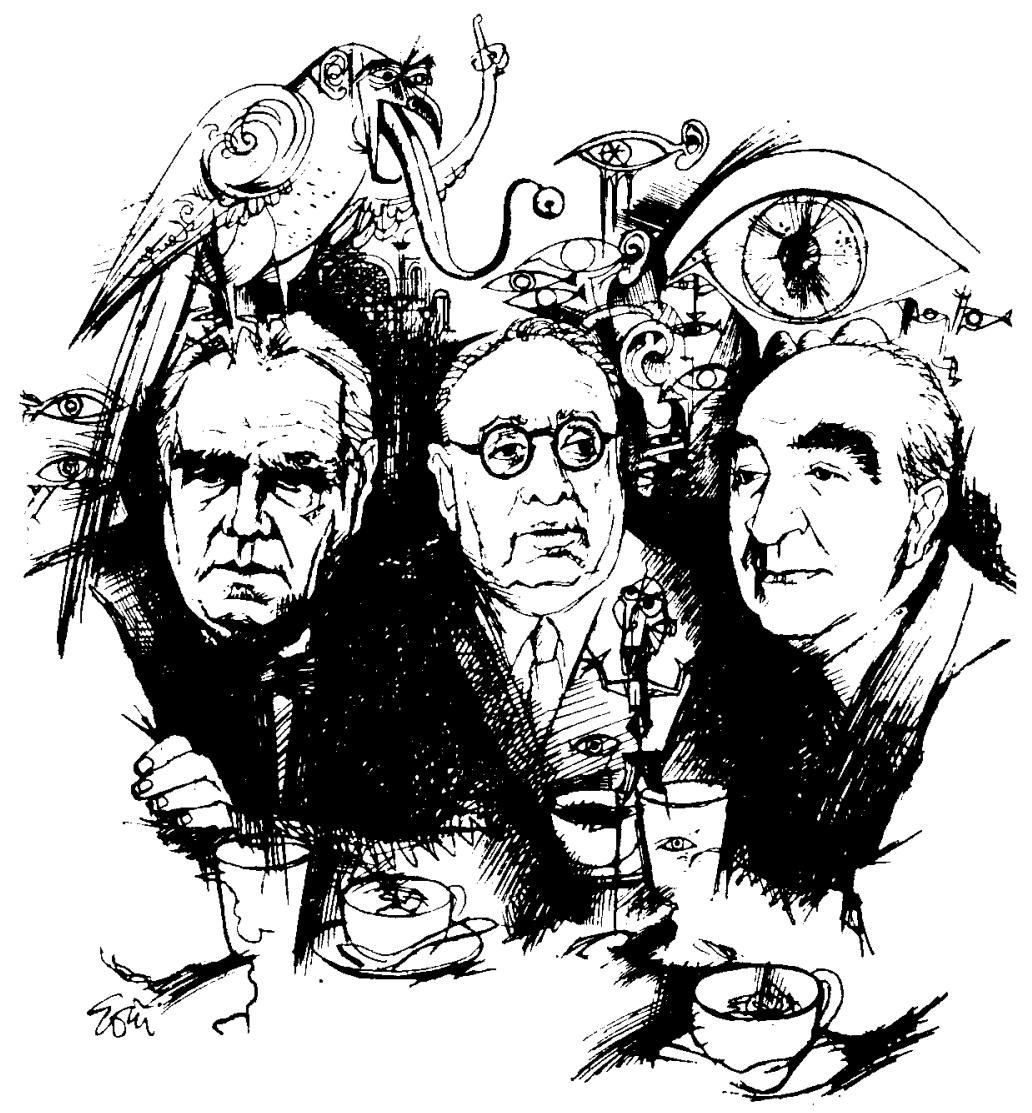

Fig. 28. Goñi: El Lyon d'Or. 


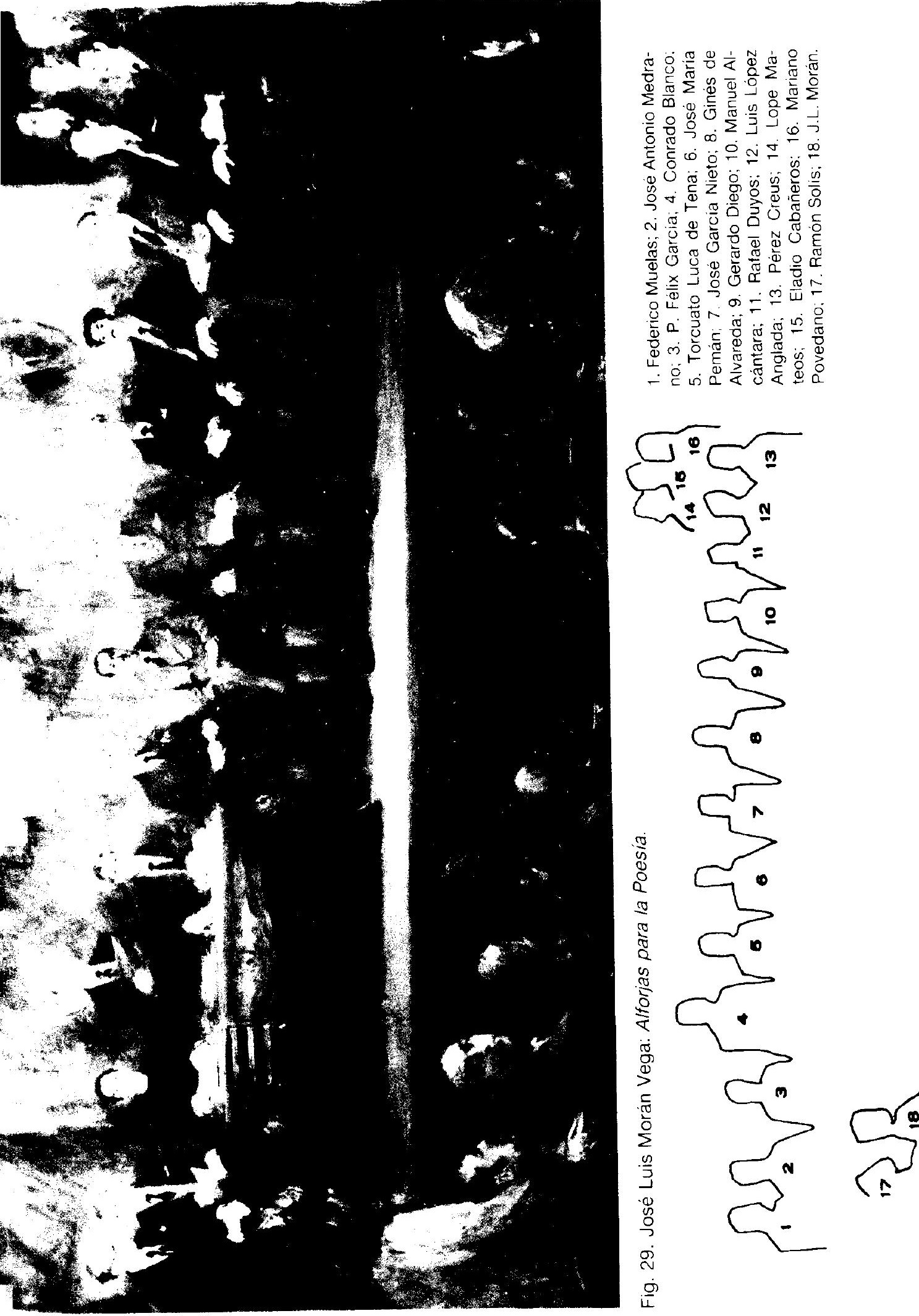




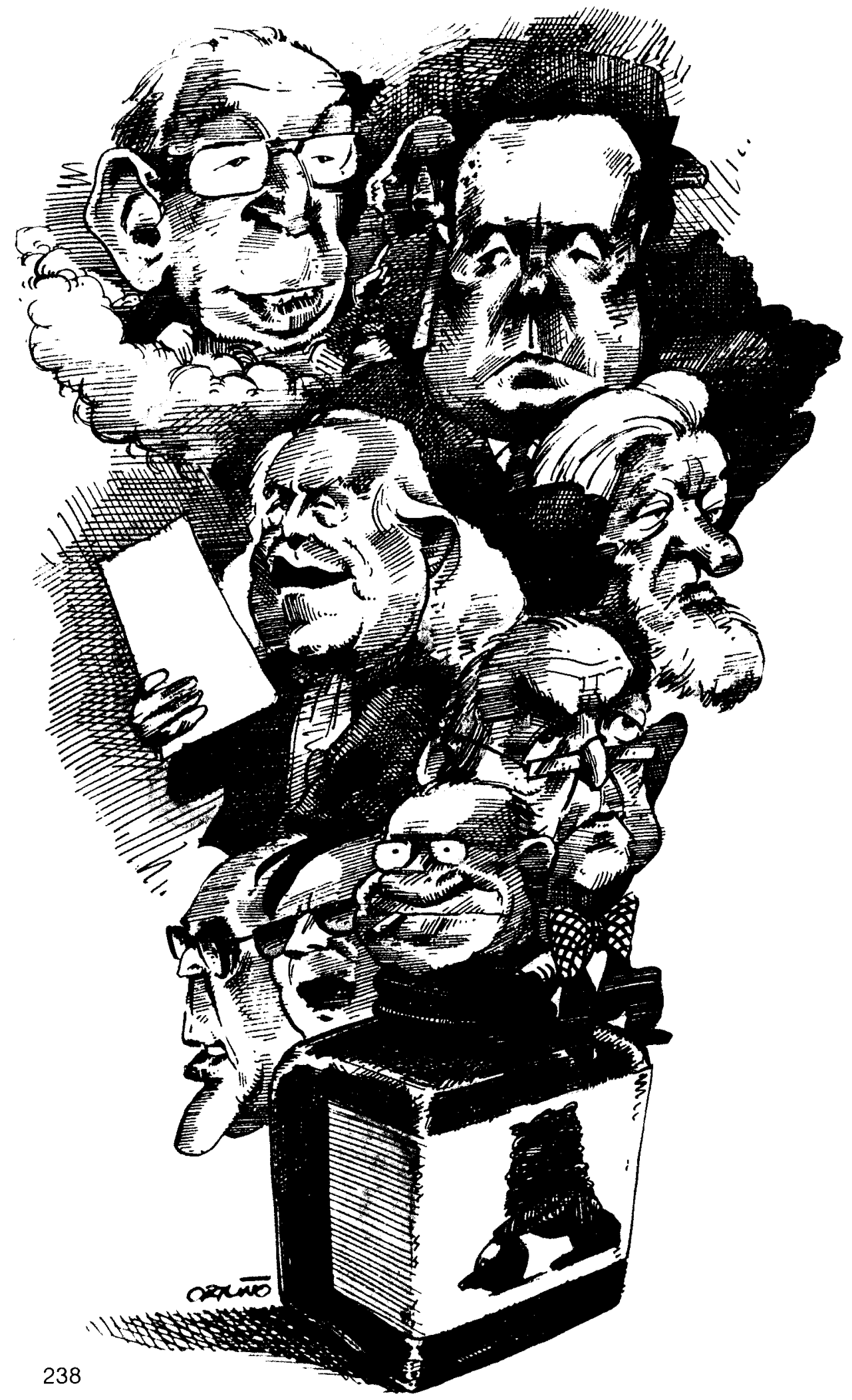

Fig. 30. Ortuño: Los politicos escritores. 